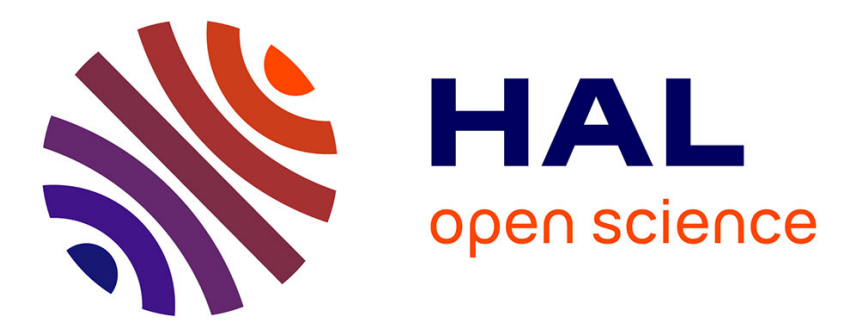

\title{
Immersion frying for the thermal drying of sewage sludge: An economic assessment
}

Carlos Peregrina, Victor Rudolph, Didier Lecomte, Patricia Arlabosse

\section{To cite this version:}

Carlos Peregrina, Victor Rudolph, Didier Lecomte, Patricia Arlabosse. Immersion frying for the thermal drying of sewage sludge: An economic assessment. Journal of Environmental Management, 2008, 86, pp.246-261. 10.1016/j.jenvman.2006.12.035 . hal-01165238

\section{HAL Id: hal-01165238 https://imt-mines-albi.hal.science/hal-01165238}

Submitted on 19 Jun 2015

HAL is a multi-disciplinary open access archive for the deposit and dissemination of scientific research documents, whether they are published or not. The documents may come from teaching and research institutions in France or abroad, or from public or private research centers.
L'archive ouverte pluridisciplinaire HAL, est destinée au dépôt et à la diffusion de documents scientifiques de niveau recherche, publiés ou non, émanant des établissements d'enseignement et de recherche français ou étrangers, des laboratoires publics ou privés. 


\title{
Immersion frying for the thermal drying of sewage sludge:
}

\section{An economic assessment}

\author{
Carlos Peregrina ${ }^{1}$, Victor Rudolph2, Didier Lecomte $^{1 *}$, Patricia Arlabosse ${ }^{1}$ \\ ${ }^{1}$ Laboratoire de Génie des Procédés des Solides Divisés (UMR 2392), Ecole des Mines d'Albi \\ Carmaux, Route de Teillet, 81013 Albi CT Cedex 09, France \\ ${ }^{2}$ Chemical Engineering, University of Queensland, St Lucia QLD 4072, Australia
}

Key words: economic, drying, frying, oil, sewage sludge

\begin{abstract}
Three different continuous process flowsheets for fry-drying sewage sludge using recycled cooking oil (RCO) as frying oil scale were simulated on a commercial scale. The main difference consisted in the systems used to manage the exhaust vapors. Simulated PROCESS 1 was supposed to condensate the water vapors with cooling water. Closed and open loops heat pumps technologies were implemented in the simulated PROCESS 2 and 3 respectively. Detailed operating conditions and equipments design for each process were obtained. Then, a technological and an economic assessment were carried out. Analysis showed that PROCESS 1 required the simplest process flowsheet, although the main equipments were the largest. This produces a small economic advantage for the heat pump processes, yet the range of accuracy of the study did not allow to conclude definitively which of the processes was the most economical. Results were then compared with available data concerning the current thermal dryers for sewage sludge. On the basis of this study, it was observed that fry-drying offers a smaller fixed capital cost per unit of processed dry solids than current sewage sludge thermal dryers. Equivalent direct manufacturing costs were found for conventional and fry-drying processes. There, it was observed that unlikely the conventional dryers, energy requirements were not the main
\end{abstract}


contributor of the fry-drying running costs but the RCO cost, which should be the focus of efforts to improve the economic performance of the fry-drying process.

\section{Introduction}

\subsection{Overview of the thermal drying of sewage sludge in the European context}

According to the European Environment Agency ( EEA) (Christiannsen, 1999), thermal drying, which refers to the removal of moisture from a substance into a gas stream (Treybal, 1980), will become a major issue in the disposal of the sewage sludge. Indeed, the dramatic increase of the volume of wastewater treated in countries belonging to the European Union forecast an increase in the production of sewage sludge. In addition, it is announced a definitive suppression of sewage sludge landfilling and sea dumping, and a corresponding increase of the two other approved disposal options namely land spreading and incineration. For both methods, thermal drying is positioned as an intermediate unit operation, allowing volume reduction, stabilization (inactivation of pathogenic biological organisms) and increase in its energy value (Grueter, et al., 1990, Hasserbrauck and Ermel, 1996).

Current thermal dryers for sewage sludge were adapted from industrial dryers used in other domains such chemicals, food or pharmaceutical (Arlabosse, 2001). Dryers are composed essentially of four systems:

1. Conveying; (Enables to feed, prepare, transport and evacuate the sludge during drying)

2. Heating; (Heats the drying gases or the beating surface of the dryer)

3. Exhaust vapors management; (Extracts and treats the emissions and sometimes recovers the energy contained in the exhaust vapors)

4. Regulation; (Controls the drying parameters such, sludge and air flows, T, P, etc.)

Three classes of dryers are reported(Chen, et al., 2002): convective or direct dryers, conductive or indirect dryers and mixed dryers . 
In the direct drying, hot gases from the combustion of oil, natural gas or the dried sludge itself, are mixed with the dewatered cake in the dryer and transport the sludge through it, evaporating the water off while in transit. Some examples of such equipments are drum, rotary, belt, spry and fluidized bed dryers. For the indirect drying, heat transfer occurs through the barrier of the dryer (e.g. thin-film, discs or paddle dryers among others). The heat carrying medium, which can be hot gas or thermal oil, is in a separate stream to the vapor. Finally, the mixed dryers, as the name implies, are a combination of above systems using both conduction and convection to evaporate the water. Further technical details can be available elsewhere in the literature (Arlabosse, 2001, Chen, et al., 2002, Lowe, 1995, Ressent, 1998).

\subsection{Opportunities to intensify the thermal drying of sewage sludge}

\subsubsection{Reduction of the energy consumption}

In order to be considered as a sustainable intermediate step for the disposal of sewage sludge thermal drying requires to be intensified from a variety of aspects. First, thermal drying is not a cost effective operation because of high-energy demand; i.e. at least the latent heat of the evaporated water (some $700 \mathrm{kWh} \cdot \mathrm{ton}^{-1}$ evaporated water), with a final product, which has a low value (Arlabosse, 2001). Consequently, energy consumption has a direct effect on the economics of the thermal dryer since it is estimated to represent between a third and a half the total running cost (Arlabosse, 2001). Indeed, its implementation is more due to environmental and social constraints than economical factors. That is the reason why wastewater treatment plants (WWTP) are usually equipped with dryers only in areas of large population densities (ADEME, 1998, Vaxelaire, et al., 2000).

In addition, since the dryers are major consumers of energy (Kudra, 2004), they are also significant contributors to non renewable natural resources consumption and to greenhouse gases production. 
A bibliographical study (Ressent, 1998), evaluate the economic and thermal performance of 44 different types of dryers that can be found in Europe. The study, which assessed facilities treating between 1280 and $1520 \mathrm{~kg}$ of total solids dried per hour, show that in general direct drying was the major energy consuming process (i.e. some $1100 \mathrm{kWh} \cdot \mathrm{ton}^{-1}$ evaporated water) followed by direct drying (i.e. some $924 \mathrm{kWh} \cdot \mathrm{ton}^{-1}$ evaporated water) and mixed drying (i.e. some 770 $\mathrm{kWh} \cdot \mathrm{ton}^{-1}$ evaporated water). Similar results were obtained when the thermal performances of four thermal drying in Europe were measured (Ressent, 1999). The average energy consumption for the indirect dryers resulted of $905 \mathrm{kWh} \cdot \mathrm{ton}^{-1}$ of evaporated water, while it was $1231 \mathrm{kWh} \cdot \mathrm{ton}^{-1}$ of evaporated water for the direct dryers.

In despite of the average tendencies presented above, it is important to notice that energy specific consumption may vary noticeable from one type of drying facility to another. In fact, Ressent (1998) reported that energy consumption for direct and indirect dryers may range from 847.1 to 1064.4 and 830 to $1140 \mathrm{kWh} \cdot \mathrm{ton}^{-1}$ of evaporated water, respectively. This means that heat losses represent generally between 25 to $60 \%$ of the thermal consumption. Such efficiencies suppose an opportunity to search new drying alternatives more adapted to the sludge and also to implement energy recovery strategies whether in the process itself or in the whole WWTP facility. Fundamental strategies to reduce the energy consumption are:

1. Avoiding the excessive consumption of energy. Since thermal drying is an intermediate operation, the place of the dryer in the whole disposal system should be carefully defined. Energy can be saved if the sludge, before thermal drying, is pre-dried until reach the limit of dewaterabilty (Vesilind and Hsu, 1997), using drainage processes such thickening and mechanical dewatering, which are minor energy consumer compared to thermal drying (Möller, 1990). Then, the degree of drying must be fixed depending on the next stages conforming the disposal system. Some times, when the sludge is incinerated on site or in burners located at relatively short distances a full drying is not required and only a partial drying can reach the auto-thermal composition of the sludge (Werther and Ogada, 1999). However, full drying 
allows further stability and conditioning of the sludge for stockage and transportation operations(Grueter, et al., 1990).

2. Using waste heat (Pinch analysis): Since high amounts of energy are involved in the thermal drying, it is possible to identify integration opportunities within a process, a plant, or a total site. In most chemical engineering processes there exist heat sources (hot process streams that need to be cooled) and sinks (cold streams that need to be heated). Instead of using utilities (e.g. steam, cooling water) to bring all process streams to their desired temperatures or conditions, a pinch analysis may be performed to exploit the heat sources and sinks in the process before using utilities, thus reducing the operating cost of a process (Cano-Ruiz and McRae, 1998). Using the biogas from a digester as dryer fuel (Couturier, et al., 2001) or the drying condensate for heating purposes in the plant (Gross, 1993) are some applications of pinch technology in the sludge thermal drying.

3. Transforming low quality into bigh quality heat. Drying vapor have an energy content that may be potentially recycled in the process reducing thus the required total heat in the operation. However, it can not be directly used since heat is not able to flow naturally from the lower temperature of the condensate to the higher temperature that is needed in the process. However, heat pumps are able to force the heat flow in that direction, using a relatively small amount of high quality drive energy (electricity, fuel, or high-temperature waste heat) (IEA, 2004). This application is still not widespread among the thermal dryer constructors, principally because of economic aspects. Few comercial models, however, show the efficacity of such technologies showing low energy consumption ranging between 130 and $560 \mathrm{kWh} \cdot \mathrm{ton}^{-1}$ of evaprated water (Arlabosse, 2001). The rapid increase of the price of fossil fuels and the concerns related to the climatic change impacts, caused by the greenhouse emissions, may support futur implementations of heat pumps in thermal drying (Kudra, 2004). 


\subsubsection{Process simplification}

The adaptation of typical dryers to the thermal drying of sewage sludge is not straightforward. The two main technical difficulties that will be described below are particular to the sewage sludge thermal drying (Lowe, 1995, Ressent, 1998). The solutions to prevent them involve high labor and maintenance costs, which rise the operating costs in a similar extent that the energy consumption(Arlabosse, 2001).

1. All types of sewage thermal dryers produce vapor containing organic volatile compounds that can create an odor nuisance or even a real risk of explosion (Ressent, 1998). This is probably the most important concern of the local planning authority who are responsible for controlling thermal drying plants. Indeed, plants can be forced to cease operation due to complaints from the local population about odor emissions or security concerns(ADEME, 1998). However, this problem becomes slight for the indirect dryers where the high evaporation rates allow the evacuation of the exhaust vapors with few amounts of carrying gases (Arlabosse, 2001, Ressent, 1998). A semi-closed or closed-loop emission management systems can effectively destruct or stabilize such substances (Hasserbrauck and Ermel, 1996) and some times act as an energy recovery system(Gross, 1993). Nonetheless, for the direct dryers, which involve a large gas stream passing over trays of the material to be dried, energy recovery involve large equipments offering mediocre results (Ressent, 1999).

2. Another technical difficulty is that from a certain total solids content (i.e. between 40 and 50\%), the sludge undergoes during the drying a particular plastic phase (Lowe, 1995). Such phase is characterized by a sticky behavior that complicates the convey of the product trough the dryer. To eases the handling of the sludge a back mixing is performed (Gross, 1993, Grueter, et al., 1990, Hasserbrauck and Ermel, 1996). This consists to return the dried sludge to the start of the process and mixed with the incoming sludge cake to increase the dry solids content up to $60-65 \%$. As a result, the residence time of the sludge and the size 
of the dryer itself increase. Moreover, for the indirect dryers, mechanical devices like knives and paddles are required to prevent the dryer from being blocked (Chavez, 2004, Ferrasse, 2000). Consequently, the more complex design of the indirect dryers produce high capital and operating costs and expensive and time consuming operations of maintenance. Indeed, Ressent (1998) reported a range of specific capital cost for direct dryers, from 815 to 2050 $€ /$ ton of total solids, whereas the indirect dryers ranged from 1280 to $2050 € /$ ton of total solids. In addition, it is estimated that for a given average operating cost almost a half is formed by maintenance and labor for the case of indirect dryers while it was just one third for the direct dryers (Arlabosse, 2001).

In summary, simplification of the thermal drying process involves, from one side, the minimization of the exhaust emissions produced during the drying, which can provide at the same time a source of energy recycling. From the other, the avoidance of the plastic phase related problems. New drying alternatives are needed to conciliate these two aspects that until now seem to be opposite.

\subsection{Introducing a new fry-drying process for the thermal drying of sewage sludge}

\subsubsection{General idea}

Frying is widely used in food processing as a cooking operation mainly because transforms original sensory qualities of foods(Moreira, et al., 1999). Nevertheless, frying could also be a very effective drying and formulating method for a large variety of products (Vitrac, 2000). Operations involving a similar solid-liquid contact for the thermal drying of sewage sludge have been proposed some years ago (Bress, et al., 1987, Kuntschar, 1996, Lue-Hing, et al., 1996), though the experimental results were not fully published. The first diffused work about the fry-drying application to the drying of sewage sludge was presented by Pires da Silva (2003a). These experimental tests were carried out by immersing a cylinder $(120 \mathrm{~mm}$ of length $\times 25 \mathrm{~mm}$ of diameter) of municipal sewage sludge into a $4 \mathrm{~L}$ vegetable oil bath which was maintained at 
different temperatures above water boiling temperature (between $120^{\circ} \mathrm{C}$ and $180^{\circ} \mathrm{C}$ ). In those conditions, it was possible to reach a final total-solids content $>95 \%$ in about 600 seconds. Moreover, due to the oil impregnation, the lower heating value (LHV) of fry-dried sludge was 24 $\mathrm{MJ} / \mathrm{kg}$ which was significantly higher to that of the same air-dried sludge at $14 \mathrm{MJ} / \mathrm{kg}$.

Afterwards, Peregrina et al. (In press-a) proposed to repeat the experiment using recycled cooking oils (RCO) instead of vegetable oils. This implementation could improve both the economic and environmental performance of the fry-drying process. That study noted that the mass and transfer phenomena occurring during the fry-drying of sewage sludge was characterized by similar drying stages to those of the frying of foods (Farkas and Hubbard, 2000). Moreover, the use of RCO did not have any discernible effect on the high rates of vaporization achieved during the fry-drying of sewage sludge, typically in the range 0.10 and $0.15 \mathrm{~kg}$ of vapor $\mathrm{kg}^{-1}$ of indigenous total solids . Consequently, RCO would act as heat medium during the process and as an improving energy value material in the final fried product. Thus, the co-disposal of two wastes by incineration would assert itself.

\subsubsection{Technical performance of the fry-drying process}

Fry-drying principle gathers some characteristics of direct and indirect dryers reducing the number of technical problems found in the thermal drying of sewage sludge. In principle, the configuration of the frying process looks as simple as direct drying, where the product is directly contacted with the heating mobile phase (i.e. frying oil) without needing any frictional device, avoiding thus the plastic phase related problems. Moreover, the water is removed by a boiling mechanism giving small amounts of exhaust vapors highly concentrated in water vapor. Hence, fry-drying is suitable to be equipped with an emission management system to treat the exhaust emission and recover the vapor latent energy.

An additional technical advantage of the fry-drying consists in the rapidness of the process. Actually, during frying the moist surface of the material dries in a few seconds and afterwards an 
evaporative front migrates towards the center of the product producing very high heat transfer rates compared to other conventional thermal drying techniques. Peregrina et al. (In press-a) have shown that such rapid kinetics is due to two simultaneous phenomena happening exclusively in the frying process. First, the water evaporation enhances the convective heat transfer coefficient because of the agitation of the oil bath. This allows an effective replacement of the heating sources even better than those taking place in the forced convection process (Tong and Tang, 1997). Secondly, it is partially demonstrated that oil penetrates into the product by replacing the removed water (Saguy, et al., 1998), enhancing thus the thermal conductivity in the dried region of the sludge. This allows to reduce significantly the drying stages that are restrained by internal heat transfer.

As noted, the oil impregnation in the final dried crusty material (also called fried sludge), increases its energy value promoting the implementation of the incineration as the final disposal of the fried sludge. Finally, it seems, that the several physico-chemical reactions taking place during the fry-drying (Graille, 1998, McGill, 1980) may stabilize the final product enabling its storage and/or transportation.

Some limitations to the application of the technique were also apparent. First, the oil impregnation does not allow agricultural land spreading or land filling (Mauvieux, 2001), thus the only final disposal method for fried sludge is incineration. Furthermore, frying oils is needed to be available. However, these constraints are not very limiting in the European context where most countries are moving to decrease land filling and land spreading of sewage sludge, with the inevitable increase of the use of incineration as a disposal method (Werther and Ogada, 1999). On the other hand, due to the food safety problems in 1999 in Europe, the market for recycled cooking oils - especially for animal feed - has decreased considerably (Mauvieux, 2001). Thus, these food industry by-products are becoming available as an oil resource with good chemical and physical stability (Boatella-Riera, et al., 2000). An alternative for recycled cooking oils (RCO) as frying oil could be the grease from wastewater treatment plants, which offers the convenience 
of being collected in the same location as the sludge. Nonetheless, further experimental and economic studies are necessary concerning the use of such waste.

\subsubsection{Environmental performance of the fry-drying process}

Further studies evaluated the environmental performance of the operation by a life cycle assessment (LCA) which compared two scenarios of the disposal of sewage sludge (Peregrina, et al., In press-b). The LCA compared a fry-dryer to a conventional indirect dryer as an intermediate step in the incineration of sewage sludge. The comparative basis was the processing of 1 ton of indigenous total solids contained in a dewatered sewage sludge. The scenario was formed by an initial thermal drying stage, then the partially dried sludge is supposed to be transported to a combustor and finally the ash formed during the incineration are transported to a landfill. In order to evaluate solely the drying performance of the entire disposal chain, the thermal drying was limited until a composition for the partially dried sludge enough to achieve an auto-thermal combustion (i.e. non needing of additional fuel to combust). Experimental and bibliographical data formed the basis of this study which analyzed 4 impact categories, namely depletion of natural resources, climate change, euthropication and acidification. Only the first two categories resulted significant in the assessment.

The results showed a lower contribution for fry-drying in terms of depletion of natural resources. In fact due to the incorporation of oil during fry-drying, the sludge LCV rises rapidly and less water needs to be eliminated in order to reach the auto thermal point. Thus, although some negative impacts are due to the larger volume of fry-dried sludge, it was shown that the economy of fuel consumption during the fry-drying step was the most important influencing factor for energy related environmental impacts.

Concerning the global warming impact, two steps were the most important contributors: the thermal drying and the incineration. In despite of the fossil fuel savings achieved during drying, the scenario using a fryer had higher effect. This was mainly due to the greenhouse emissions 
released during the incineration that corresponded to the fraction of oil impregnated in the fried sludge. However, authors put into perspective such results because the goal of the study was the disposal of the sewage sludge rather than the co-disposal of both wastes (i.e. RCO and sewage sludge). It was suggested that the inclusion of the adverse environmental impacts due to an alternative disposal method for the recycled cooking oil may balance the results of this impact category benefiting thus the environmental profile of the fry-drying scenario.

Since the fry-drying process has shown both environmental and technical advantages, an economic study is now necessary to demonstrate the feasibility of a such process in an industrial context. The study presented in this paper aims to develop an "economic assessment" of a simulated fry-drying process operating at the defined lab-scale experimental conditions described by Peregrina et al.(In press-a). Despite some expected differences between process simulation results and actual process operation, most current simulation software can provide reliable information on process operation because of their comprehensive thermodynamic packages, vast component libraries and advanced calculation techniques (Zhang, et al., 2003a). The process simulation software, ASPEN 10.1 (Aspen Technology Inc.), was used in this research. Three fry-drying process will be proposed, simulated and economically assessed.The first is supposed to be equipped with a simple condenser to recover low value energy contained in the condensate. The two other would use a closed and an open heat pump respectively to recycle high value energy.

\section{Theory and calculation}

\subsection{Basis of the assessment}

Adequate drying capacity depends on the prevailing conditions of the WWTP. Criteria such product quality, building situation, integration into existing plant conception, opportunity of using waste heat and of course economic viability influence this choice. In this study, the determination of the dryer capacity was based on three factors: 
1. Fry-drying offers a good environmental profile when it is aimed to incinerate the friedsludge (Peregrina, et al., 2005b). Consequently, in this work it is supposed to operate in the same conditions as described elsewhere in the LCA study of the fry-drying (Peregrina, et al., 2005b). Thus, mechanically dewatered sewage sludge with 19\% total solids will be fry-dried until reaching its auto-thermal composition (i.e $3.7 \mathrm{~kg}$ of water $\mathrm{kg} \cdot \mathrm{kg}^{-1}$ of indigenous total solids and $0.35 \mathrm{~kg}$ of $\mathrm{RCO} \cdot \mathrm{kg}^{-1}$ of indigenous total solids) with a lower heating value of $4.11 \mathrm{MJkg}^{-1}$.

2. Although several convective dryers do not stop operating throughout the year (Grüter, et al., 1990, Ressent, 1999), most thermal dryers of sewage sludge work intermittently (Hasserbrauck and Ermel, 1996, Ressent, 1998, 1999). Consequently, the process simulated in this paper is assumed to operate 12 hours daily (i.e. one shift and a half per day) at a total dry solids processing rate of $1 \mathrm{ton} \cdot \mathrm{h}^{-1}$ of total dry solids.

3. According with the factors described above, the total dry solids processed annually is estimated in 4380 ton. Since the French per capita production is estimated in $20 \mathrm{~kg}$ total dry solids $\cdot \mathrm{EqH}^{-1}$ (Munck-Kampmann, 2001), the simulated dryer would be capable to process the sewage sludge of a WWTP of about $219000 \mathrm{EqH}$, which is a common size for the facilities equipped with a thermal dryer (Gross, 1993, Grüter, et al., 1990, Hasserbrauck and Ermel, 1996, Ressent, 1999). This basis is in agreement with the availability of RCO in France. Indeed, Sud Recupération, a RCO recycler in the South of France and one of the major recyclers in the French market, collects some 6000 ton of the estimated 30000 tons of RCO produced in a year (SudRecupération, 2003). Thus, the simulated facility will be able to handle one fraction of the regional RCO, by consuming 1533 tons yearly. 


\subsection{Economic assessment}

According to the definition of capital cost estimation provided by Turton et al. (1998), the economic estimation in this article is classified as a "study estimate". It is based on the development of a process flow diagram and rough sizing of major process equipment. No further information, such as a layout plot, process instrumentation diagram or piping and instrumentation requirement, were considered. Turton et al. (1998) consider that this level of study has a range of expected accuracy from $+30 \%$ to $-20 \%$. Thus, results from such a preliminary evaluation may not accurately reflect the final profitability of a plant but can be used as a tool for comparison of several processes(Zhang, et al., 2003b). In the present study "economic assessment" refers to the evaluation of a Total Capital investment cost $\left(\mathrm{C}_{\mathrm{TC}}\right)$ and a Total Manufacturing cost $\left(\mathrm{C}_{\mathrm{TM}}\right)$ (Turton, et al., 1998, Urich, 1984).

Following Turton et al. (1998), $\mathrm{C}_{\mathrm{TC}}$ is given by the sum of the Fixed Capital cost $\left(\mathrm{C}_{\mathrm{FC}}\right)$, which is all the costs associated with building a facility and the Working Capital cost $\left(\mathrm{C}_{\mathrm{wC}}\right)$, which is the amount of capital required to start up the plant and finance the first few months of operation. It is obtained as a fraction $(15 \%)$ of the $\mathrm{C}_{\mathrm{FC}}$. Fixed Capital cost $\left(\mathrm{C}_{\mathrm{FC}}\right)$ consist on the following three parts:

1. Total bare module capital cost $\left(C_{B M}\right)$ which is the sum of the cost of each piece of equipment in the process;

2. Contingencies and fees $\left(C_{C F}\right)$ to cover unforeseen circumstances and contractor fees, it is defined as a fraction of the $\mathrm{C}_{\mathrm{BM}}$ (e.g. $18 \%$ was used in this study);

3. Cost associated with auxiliary facilities $\left(C_{A C}\right)$ such as the purchase of land, installation of electrical and water systems etcetera. The authors recommend to use $30 \%$ of the sum of the total $\mathrm{C}_{\mathrm{BM}}$ and the $\mathrm{C}_{\mathrm{CF}}$.

Estimation of $\mathrm{C}_{\mathrm{FC}}$ is consequently straightforward when the $\mathrm{C}_{\mathrm{BM}}$ is known. To determine $\mathrm{C}_{\mathrm{BM}}$, size equipment and materials flow rates where calculated from the ASPEN PLUS TM 11.1 simulation software (ASPEN Tech Inc., USA). Equipment prices were updated from available 
1990 (Peters and Timmerhaus, 1991), 2001 (Turton, et al., 2003) and 2003 (Sud-Recupération, 2003) to 2005 values using the preliminary March 2005 Chemical Engineering Plant Cost Index $\left(\right.$ CEPCI) (Vatavuk, 2002), where $\mathrm{I}_{1990}=357.6, \mathrm{I}_{2001}=397, \mathrm{I}_{2003}=402$ and $\mathrm{I}_{2005}=468.1$.

Total Manufacturing cost $\left(\mathrm{C}_{\mathrm{TM}}\right)$ is usually divided into three categories: direct manufacturing costs, indirect manufacturing costs and general expenses (Turton et al., 1998, Urich, 1984). All charges related to raw materials and labor are considered direct manufacturing costs while all the items which are independent of the production rate belong to the indirect manufacturing costs. Raw material and auxiliary facilities requirements are given by the simulated process streams.

Considering the absence of definitive labor data, operator requirements were derived from the flow sheet and major equipment following the method proposed by Alkayat and Gerrard (1984). General expenses includes administrative and distribution costs and research and development charges as well. Both indirect and general manufacturing expenses are calculated by factoring methods which are widely used in economic assessment (Turton, et al., 1998, Urich, 1984, Zhang, et al., 2003b) and presented in Table 6 of this paper.

\subsection{Process Simulation}

The procedures for process simulation mainly involve defining chemical components, selecting a thermodynamic model, determining plant capacity, choosing proper operating units and setting up input conditions (flowrate, temperature, pressure, and other conditions)(Zhang, et al., 2003a). The fry-dryer and the heat pumps studied in this paper were simulated taking into account the following limitations.

\subsubsection{Simulation of the fry-drying unit}

The unusual nature of the frying process, including the absence of thermal equilibrium between the frying oil and the water vapor and the non conventional materials involved in the process, require the ASPEN PLUS ${ }^{\mathrm{TM}} 11.1$ predetermined blocks to be suitably configured to 
describe the heat and the mass transfers occurring during the frying. Consequently, a pseudo-unit operation was used to simulate and calculate the heat and mass balances (See Figure 1).

According to experimental data (Peregrina, et al., 2005a) fry-drying of sewage sludge is most suitable when the frying temperature ranges from 140 to $160{ }^{\circ} \mathrm{C}$. Under those temperatures, a residence time of about 100 seconds is necessary to reach the target auto-thermal composition of the final fry-dried sludge(Peregrina, et al., 2005b). In this simulation it is assumed that the frying temperature is $160^{\circ} \mathrm{C}$, permitting the frying oil temperature to decrease by $20^{\circ} \mathrm{C}$ during frying with out affecting neither the frying performance nor the residence time of the sludge. Water evaporation and the cooling of the fry-drying oil is simulated using the following strategy:

A mixture of water and total dry matter (defined in ASPEN 11.1 as non conventional component according to its proxy, ultime and sulfanal analysis) forms the sewage stream (stream 1 in Figure 1) that is fed into a flash separator (V-101A) which describes the water evaporation. The Ridlich-Kwong-Soave (RKS) equation of state was used to model this part of the process (Twu, et al., 1998, Twu, et al., 2002). Separately, an auxiliary block (V-101B) calculated the cooling of the frying oil and the information is transferred to the flash separator in order to equilibrate the heat and mass balances. In the external heat exchanger (E-101), medium pressure steam $(\mathrm{P}=9$ atm and $\left.\mathrm{T}_{\text {sat }}=449 \mathrm{~K}\right)$ condensates to provide the energy (Q1) for the drying and to raise the temperature of the fed new frying oil stream (stream 2-NEW in Figure 1). Other two auxiliary blocks, one splitter (V-101C) and one mixer (V-101D), simulate the oil impregnation into the partially dried sludge (stream 1-DRY in Figure 1). This is achieved by separating some oil (2-IMP) from the recycling oil stream (2-COLD) using the splitter (V-101C) and then it is combined with the dried sludge using mixer (V-101D) resulting in stream 3, the final fried sludge.

Recycled cooking oil was also calculated as non conventional component. Once that leaves the fry-drying unit (stream 2-RECYCL in Figure 1) is mixed (2-MIX) with the incoming RCO to give (2-MIXA) and then pumped (2-MIXB) towards the heat exchanger (E-101). The resulting heated oil (2-HOT) will provide the heat needed to the fry-drying and will become (2-COLD). 
Exhaust vapor stream (4-VAP) will be condensed differently in each of the three process investigated to recover the latent heat energy.

The obtained results allow to calculate the volume of enclosed frying vessel which holds the frying oil. The accessories, such the belt conveyor and the fan to remove the volatiles (Stier, $1996 \mathrm{a}, \mathrm{b}, \mathrm{c})$ as well as the circulation pump which enables the frying oil to circulate through the drying vessel and heater, were size as a basis for costing according to some empirical data provided elsewhere by Perry and Green (1997) and Turton .

\subsubsection{Simulation of the heat pumps}

The great majority of heat pumps work on the principle of the vapor compression cycle (IEA, 2004). The main components in such a heat pump system (See Figure 3) are the compressor (C201 and C-202), the expansion valve (C-203) and two heat exchangers referred to as evaporator (E-201) and condenser (E-202). The working fluid or refrigerant, circulates through the four components.

Traditionally, the most common working fluids for heat pumps have been the chlorofluorocarbons, but these due to their chlorine content and chemical stability are harmful to the global environment (Tsai). Consequently, the European Union has adopted an accelerated elimination schedule for these substances which requires them to be phased out by 2015 (Powell, 2002). As a result for new heat pumps applications blends of refrigerants or natural working fluids are preferred (IEA, 2004, Riffat, et al., 1997).

Among the possible working fluids suggested by the International Energy Agency (IEA) water has been chosen for this simulation because it has favorable thermodynamics properties and is intrinsically safe. Typical operating temperatures are in the range from $80^{\circ} \mathrm{C}$ to $150^{\circ} \mathrm{C}$, although there are some examples where it can work at temperatures up to $300^{\circ} \mathrm{C}$ (IEA, 2004). The major disadvantage with water is its low volumetric heat capacity $\left(\mathrm{kJ} \cdot \mathrm{m}^{-3}\right)$ which requires large and expensive compressors (IEA, 2004). 
In order to be able to work under the range of temperatures where water is useful as refrigerant two options can be imagined. One alternative implies to design the heat pump to preheat the frying oil until the upper operating temperature for water cycles (i.e. $150^{\circ} \mathrm{C}$ ). Consequently, only one part of the heat duty that is required for the fry-drying process will be provided by the energy recovery system and therefore a complementary steam generator will be required. The other alternative is to imagine the frying process performing below atmospheric pressure and therefore at lower frying temperatures. Although vacuum conditions and low temperatures may be an environmental outcome by reducing the production and release of gas emissions during fry-drying, it is difficult to economically assess since there are not industrial references about similar processes and vacuum fryers existed only for $R \& D$ activities, even in food applications(Garayo and Moreira, 2002). As a result, only the first alternative was simulated in this paper.

The pure water-steam equilibrium considered to simulate the heat exchanger in the heat pumps was calculated using the thermodynamic model Steamnbs proposed by the ASPEN PLUS data base. The water mass flow was minimized with the option Design Specification by targeting a liquid fraction of 1 or 0 depending on the phase change. The surface of exchange was determined using the simplified method of the block HeatX in ASPEN PLUS 11.1 (Aspen Tech, Inc.), considering that the heat exchanger block operates under an appropriated constant overall heat transfert coefficient (Perry and Green, 1997, Sinnott, 1991). Finally, the compressor were calculated by the ASME method provided by ASPEN PLUS 11.1, considering a polytropic compression with an efficiency of 0.65 (Peters and Timmerhaus, 1991). The three energy recovery systems that are examined as case studies in this paper are described below. 


\subsection{Process Design}

\subsubsection{PROCESS 1: Fry-dryer with a condenser as an energy recovery system}

PROCESS 1 (See Figure 2) represents a typical external heated continuous fryer like those widely used in the food industry (Stier, 1996a). In this configuration the frying oil is passed through a heat exchanger heated with steam vapor (stream 5-VAP in Figure 2; $\mathrm{P}=9$ atm, $\mathrm{T}=449,6 \mathrm{~K})$ an returns directly to the fryer.

The frying unit operation works at atmospheric pressure. The frying oil input and out put temperatures are $433 \mathrm{~K}$ and $413 \mathrm{~K}$ respectively. Exhaust vapor (4-VAP) are condensed (4COND) at $368.15 \mathrm{~K}$, in (H-201) using cooling water (6B). Latent energy is not recovered although the hot condensate is available for use elsewhere in the plant as if there is an use.

To improve the quality of the exhaust vapor heat, so that it can be recovered in the process, it was proposed to apply a vapor compression cycle (IEA, 2004) as described in Process 2 and 3.

\subsubsection{PROCESS 2: Fry-dryer with a closed heat pump as an energy recovery system}

In the closed loop heat pump provided in PROCESS 2 (Figure 3), water vapor (6A) is formed at $\mathrm{P}=0.7 \mathrm{~atm}$ and $\mathrm{T}_{\mathrm{sat}}=366.67 \mathrm{~K}$, in the condenser (E-201) of the fry-drying exhaust vapors (4VAP). Then, it is compressed in the heat pump at $\mathrm{P}=4.0 \mathrm{~atm}(\mathrm{~T}$ sat $=418,74 \mathrm{~K})$. In order to reduce the maintenance costs the compression, two stages were required (C-201 and C-202) (Turton, et al., 2003, Urich, 1984). Due to the limited range of operational temperatures for the working fluid, the energy recovered in the condenser of the closed loop (E-202) gives only one fraction (Q4) of the required total heat duty (Q1). Q1 enables just the preheating of the frying oil (2-PREHOT) until a temperature of $423.69 \mathrm{~K}$. The rest of the heat (Q3) will be provided by a fuel gas powered steam generator (H-101), similarly to process 1.

In the closed loop, the stream of high pressure vapor $(6-C)$ condensates in the pre-heater and then is expanded in (C-203) to $\mathrm{P}=0.9 \mathrm{~atm}$, this stage involves the re-vaporization of one fraction of the liquid water. To condensate it, a pre-heater (E-203) for the incoming sewage (1) sludge was 
simulated. This will increase the energy recovery capacity of the heat pump by reducing the required total duty heat in the frying unit and therefore the amount of required frying oil (2HOT).

\subsubsection{PROCESS 3: Fry-dryer with a open heat pump as an energy recovery system (Mechanical Vapor} compression)

PROCESS 3 (See Figure 4) is formed essentially for the same elements that PROCESS 2. The only difference is that in open systems, exhaust vapor from the fry-drying operation (4-VAP) is directly compressed to a higher pressure and thus a higher temperature $(\mathrm{P}=4$ atm and $\mathrm{Tsat}=$ 478.74), and then condensed (4-CONDA) to giving off heat, which is transferred to the frying oil (2-MIXB) in a heat-exchanger (E-202). Similarly to PROCESS 2, the limits of the operating temperatures for the current open systems (i.e. heat source temperatures from 343-353 K and deliver heat between 383 and $423 \mathrm{~K}$ (IEA, 2004)), make that the recompressed vapor process simulated in this paper will provide only one part of the heat duty and a fuel gas powered steam generator (H-101) will be needed to increase the frying oil temperature to $433.15 \mathrm{~K}$.

In order to improve the energy recovery efficiency, it was proposed, likewise to PROCESS 2, that the vapor and liquid water mixture (4-MIX) formed after the expansion (C-203) of the high pressure water liquid (4-CONDA) until ambient pressure, is passed trough a sewage sludge preheater (E-203) before to be released as heating liquid (4-CONDB) to be used elsewhere in the plant.

\section{Results}

\subsection{Technical process comparisons}

The basis and assumptions adopetd in this study are summarized in Table 1. From there, a first technical comparison of the three different process can be done if it is considered, the number of major processing units in each process (Table 2), the characteristics of each equipment (Table 3) as well as the utilities required in every process (Table 5). 
The simplest fry-drying process is given by the PROCESS 1, which requires only five main equipments versus nine and eight for the PROCESS 2 and 3 respectively (Table 2). Consequently, those processes will require, according to Alkayat and Gerrard (1984), seven workers to cover the year round working time, whereas only six men will be needed to run PROCESS 1. The difference in the number of equipment is made by the compressors and the supplementary heat exchangers that are required in the heat pumps. However, in spite of its simplicity, PROCESS 1 will be equipped with the largest heat exchanger and fuel gas powered steam generator (Table 3).

Concerning the utilities of the different processes, the heat pumps reduce the needs in fuel gas in more than $50 \%$ and avoids the excessive use of cooling water, needed to condensate the exhaust vapors of PROCESS 1 (Table 5). Nonetheless, such reduction is affected by the electrical energy requirements related to the compressors used in PROCESS 2 and 3 (Table 5).

It was also observed that the strategy of pre-heat the incoming sewage sludge (1) reduces the total heat duty required in the fry-drying operation (Q1) only in a slight extent. Consequently, the impact in the reduction of the amount of pumped RCO (2-MIXB) (Table 5), which determines the fryer volume (V-101A, B, C, D) as well as the pump capacity (P-101) (Table 3), is small.

\subsection{Economic process comparisons}

\subsubsection{Fixed capital cost}

The accuracy range is too great to definitively conclude which of the 3 processes is the most economical in terms of fixed capital cost. However, equipment costs results given in Table 4 show that the highest total capital investment is for the PROCESS 1, whereas the lowest is for the PROCESS 3 - open heat pump.

Even though PROCESS 1 is the simplest Process Flow Diagram (PFD), the data indicates that the heat duty required for a fry-drying process is highly expensive when produced by fired heaters (Urich, 1984). Consequently, due to the absence of energy recovery system, PROCESS 1 
requires a much larger and expensive steam generator, which contributes in almost $60 \%$ of the total bare module cost.

A closed heat pump presents an intermediate capital cost but the most complicated (PFD) in terms of the number of necessary equipment pieces. Furthermore, currently available closed heat pumps technology is not well adapted to the fry-drying process, noting that fry-drying requires a $\Delta \mathrm{T}$ of some tens of degree Kelvin. The configuration requires expensive equipment but delivers on a poor energetic return.

Finally, the most economical total capital investment based on the method used corresponds to PROCESS 3. In fact, the issues presented in the PROCESS 2 fall away in this new configuration where water does not need to be re-condensed in a closed lop. Thus, water produced in the fry-drying is increased in temperature to heat the frying oil and afterwards it is cooled with a high energetic efficiency in a relatively simple PFD.

According to this study, the fixed capital cost referred to the ton of processed dry solids is estimated in 324, 275 and 232 USD ton $^{-1}$ of TS for PROCESS 1, 2 and 3 respectively.

\subsubsection{Manufacturing cost}

Direct manufacturing costs in this simulation was calculated from the results of the simulation (Table 5) and based on the actualized costs of raw materials (Sud-Recupération, 2003), salaries (INSEE, 2005) and utilities (Turton, et al., 2003). All the indirect and general expenses have been calculated from the factorial information related to a typical chemical engineering plant proposed by Turton et al.

The capital manufacturing costs are summarized in Table 6 , and have been based on the assumption that the fry-dryer will work one and a half shifts per day (i.e. 12 hours per day; 4380 hours a year) giving a yearly processing of 4380 ton of auto thermal partially fry-dried sludge to yield a production of 21244 ton of fry-dried sludge. 
Similarly that for the capital cost, within the accuracy of the study, the manufacturing costs $\left(\mathrm{C}_{\mathrm{TM}}\right)$ for each process are equivalent and it can not be concluded definitively which of the process is the most economical. However, they provide valuable information concerning the composition of the $\mathrm{C}_{\mathrm{TM}}$ that highlights the issues where an attention should be put in order to minimize the running costs of the proposed processes.

According to Table 6 , it is observed that indirect $\left(\mathrm{C}_{\mathrm{IM}}\right)$ and general expenses $\left(\mathrm{C}_{\mathrm{GE}}\right)$ for the three processes represent $20-19 \%$ and $17-18 \%$ of the $\mathrm{C}_{\mathrm{TM}}$ respectively, whereas direct manufacturing costs $\left(\mathrm{C}_{\mathrm{DM}}\right)$ range between $62-64 \%$. As a result, $\mathrm{C}_{\mathrm{DM}}$ should be the focus to reduce the manufacturing costs.

Concerning the most important contributors of the $\mathrm{C}_{\mathrm{DM}}$, it is important to notice that, unlikely most of the thermal drying, energy requirements are not the main items (Arlabosse, 2001, Ressent, 1998). In fact, due to the few water evaporation that is needed to prepare the autothermal fry-dried sludge only 10 to $14 \%$ of $\mathrm{C}_{\mathrm{DM}}$ correspond to electricity and natural gas costs. In fact, oil penetration in the fried sludge contributes enormously to the final lower heating value of the sludge but involves a consumption of the RCO in the process. As a result, the fry-drying process needs an additional raw material: the frying oil. Thus, the RCO costs represent about 52$54 \%$ of the direct manufacturing costs and appear to play the most important role in the total manufacturing costs.

The other important expense is formed by the operating labor expenses, which is estimated in 25 to $29 \%$ of $\mathrm{C}_{\mathrm{TM}}$ (Table 6), depending on the number of main processing units appearing in the flow sheet for each process. Finally, fry-drying may be expected to have a competitive level of maintenance and repairs costs among the conventional sludge dryers due to the absence of frictional parts in the frying vessel and the small amounts of exhaust vapors to manage. 


\subsubsection{Economic performance of frying as a thermal drying process for sewage sludge}

Available data concerning current sewage sludge industrial dryer is available from Goss (1993), Grüter et al. (1990), Hasserbrauck and Ermel and Ressent (1998, 1999). Although it is difficult to strictly compare the fixed capital and manufacturing costs of real dryers with those of the simulated processes- mainly due to the different aims of each drying facility- these data illustrate the order of magnitude of the competing systems and give a reference about the economic performance of using frying for thermally dry the sewage sludge.

Table 7 summarizes some reported capital costs and capacities for sewage sludge thermal drying facilities that are currently operating in Europe. There, it is possible to notice that the reported ratio between the fixed capital cost and the yearly tonnage of total dry solids for the current dryers are some times higher than those expected for the simulated fry-drying processes in this paper.

As expected, the difference is still bigger for smaller dryer facilities as verified in a bibliographical study reported by Ressent (1998), where the author economically assessed thirteen conventional models for the thermal drying of sewage sludge having a yearly capacity comprised between 1230 and 2960 tons of total dry solids. The updated results show an average ratio for the indirect dryers of about 2323 USD of investment ${ }^{-1}$ ton $^{-1}$ of dry solids and another for the direct dryers of 1615 USD of investment'ton ${ }^{-1}$ of dry solids.

In the same study, the author observed the direct manufacturing costs without including the final disposal expenses (i.e. transportation, incineration, etc.) for each facility and determined an average cost for the direct and indirect dryers, which once updated is about 190 USD of direct manufacturing cost ${ }^{\cdot} \operatorname{ton}^{-1}$ of dry solids. From the information reported in Table 6 , it is possible to determine a specific direct manufacturing costs for the simulated fry-drying processes of about 202, 199 and 194 USD of direct manufacturing cost ton $^{-1}$ of dry solids; for PROCESS 1, 2 and 3 respectively. Although the estimated running costs are similar, it is important to notice that they are conformed differently (Figure 5 and 6). Thus, the concepts related to maintenance and energy 
requirements are very important for indirect and direct dryers, whereas RCO consumption is the main contributor for the fry-drying processes. Thus, one way to improve the economical performance of fry-drying running costs is to find more economical frying oils, for example trap waste. Another is to find more economical heating sources. Since fry-dried sludge has good calorific characteristics, the final fry-dried sludge could substitute the natural gas or any other fossil fuel. Doing that -as is apparent in Table 6- an economic advantage may be produced. Moreover, since the use of biomass for energy can also save the natural resources, an important environmental outcome could also achieved. Nevertheless, in order to do that, the fry-dried sludge burner must be designed and considered into a new economic assessment. Alternatively, the dried sludge could be used as a fuel additive for the electricity generator. Further studies may confirm these hypotheses.

Finally, it is important to recall that the fry-drying process simulated in this paper offers only a small volume reduction of the waste, because only few amounts of water are removed and some oil is added. Thus, the subsequent stages of transportation are expected to be more expensive than for the conventionally dried sludge. As a consequence, it is preferable to foresee the application of the fry-drying of sewage sludge only for the facilities equipped with an incineration unit or located close to an incinerator.

\section{Conclusions}

For a yearly processing of 4380 ton of dry solids, three fry-drying processes were designed and simulated. Due to the unusual nature of frying process, including the absence of thermal equilibrium between the frying oil and the water vapor and the non conventional materials involved in the process a pseudo-unit operation was used to simulate and calculate the heat and mass balances. The main difference of the process consisted in the proposed exahaust vapors management systems. PROCESS 1 condensed the vapors using cooling water, whereas PROCESS 2 and 3 used a closed and open heat pump respectively, to recover the latent heat of 
the vapors to bring back one fraction of the heat duty required in the process. From the technical assessment, all these processes proved to be feasible to produce an auto-thermal fry-dried sludge under reasonable operating conditions.

PROCESS 1 had the simplest process flowsheet diagram (PFD) with the least amount of process equipment but had a lower economic performance than the other two processes. In fact, since no energy recovery is performed, the high energy requirements required larger and therefore more expensive equipments as well as larger amounts of fuel utilities.

PROCESS 2 had an intermediate economic performance but involves the most complicated PFD. Indeed, currently available closed heat pumps technology is not well adapted to the frydrying process, noting that fry-drying requires a $\Delta \mathrm{T}$ of some tens of degree Kelvin. The configuration requires expensive equipment but delivers on a poor energetic return.

PROCESS 3 seems to offer the more well adapted technology for the fry-drying process among the three proposed processes. the issues presented in the PROCESS 2 fall away in this new configuration where water does not need to be re-condensed in a closed lop. Thus, water produced in the fry-drying is increased in temperature to heat the frying oil and afterwards it is cooled with a high energetic efficiency in a relatively simple PFD.

The accuracy range is too great to definitively conclude which of the 3 processes is the most economical. However, when comparing with available data related to current sewage sludge thermal drying systems, it was observed that the fry-drying fixed costs referred to one ton of processed dry solids is some times lower than those of conventional dryers. It was also observed that direct manufacturing costs for the simulated process are equivalent to those of the conventional processes when the final disposal expenses are not included, although in the frydrying the energy and maintenance costs are overwhelmed by the RCO costs, which is the most important contributor of the running costs. Consequently, one way to improve the economical performance of frying oil is to find more economical frying oils, for example trap waste; another is to use the good calorific characteristics of the final fry-dried sludge to substitute the natural gas 
or any other fossil fuel used in the process. Doing that an economic advantage may be produced. Moreover, since the use of biomass for energy can also save the natural resources, an important environmental outcome could also achieved. Nevertheless, in order to do that, the fry-dried sludge burner must be designed and considered into a new economic assessment. Alternatively, the dried sludge could be used as a fuel additive for the electricity generator. Further studies may confirm these hypotheses. 


\section{Tables caption}

Table 1 - Basic conditions for the simulation of each process

Table 2 - Number of main processing units required for each process.

Table 3 - Description of operating conditions of main equipment

Table 4 - Equipment and fixed capital costs of the simulated fry-drying processes

Table 5 - Description of utilities required for each process

Table 6 - Total manufactring cost of the simulated fry-drying processes

Table 7 - Approximate fixed capital costs of current sewage sludge thermal drying facilities in Europe 


\section{Tables}

Table 1, "A new application of immersion frying for the thermal drying of sewage sludge: An economic assessment” by C. Peregrina, D. Lecomte, P. Arlabosse and V. Rudolph.

\begin{tabular}{|c|c|c|}
\hline Condition & Assumption & Reference \\
\hline Plant capacity & 4380 tons of total dry solids $\cdot y^{-1}{ }^{-1}$ & \\
\hline WWTP size & 219000 & $\begin{array}{l}\text { (Munck-Kampmann, } \\
\text { 2001) }\end{array}$ \\
\hline Thermodynamic model & $\begin{array}{c}\text { Redlich Kwong Soave, NBS steam } \\
\text { tables and ASME method to calculate } \\
\text { polytropic compressors }\end{array}$ & Aspen Tech \\
\hline Residence time & $100 \mathrm{~s}$ & (Peregrina, et al., 2005b) \\
\hline Range of the frying temperature & $413.15-433.15 \mathrm{~K}$ & (Peregrina, et al., 2005a) \\
\hline $\begin{array}{l}\text { Auto-thermal composition of the } \\
\text { final fry-dried sludge }\end{array}$ & $\begin{array}{l}\xi_{\mathrm{W}}=3.5 \mathrm{~kg} \text { water } \cdot \mathrm{kg} \text { total dry solid } \\
\xi_{\mathrm{RCO}}=0.35 \mathrm{~kg} \text { oil } \cdot \mathrm{kg} \text { total dry solid }\end{array}$ & (Peregrina, et al., 2005b) \\
\hline $\begin{array}{l}\text { Final temperature of the } \\
\text { condensed fry-drying vapors }\end{array}$ & $368.15 \mathrm{~K}$ & (Gross, 1993) \\
\hline \multirow{3}{*}{ Overall heat transfer coefficient } & $\mathrm{U}_{0}=230 \mathrm{~W} \cdot \mathrm{m}^{-2} \cdot \mathrm{K}^{-1}$ (sludge-steam) & $\begin{array}{c}\text { (Yamahata and Izawa, } \\
1985)\end{array}$ \\
\hline & $\mathrm{U}_{0}=250 \mathrm{~W} \cdot \mathrm{m}^{-2} \cdot \mathrm{K}^{-1}$ (RCO-steam) & (Perry and Green, 1997) \\
\hline & $\mathrm{U}_{0}=1250 \mathrm{~W} \cdot \mathrm{m}^{-2} \cdot \mathrm{K}^{-1}$ (steam-water) & (Perry and Green, 1997) \\
\hline Medium pressure steam & $\mathrm{P}=9 \mathrm{~atm}$ & $\begin{array}{c}\text { (Ressent, 1999, Turton, et } \\
\text { al., 2003) }\end{array}$ \\
\hline $\begin{array}{l}\text { Operating working fluid in the } \\
\text { heat pump }\end{array}$ & Water between $253.15 \mathrm{~K}$ and $423.15 \mathrm{~K}$ & (IEA, 2004) \\
\hline \multirow{3}{*}{ Efficiencies } & Compressor $=0.65$ & $\begin{array}{l}\text { (Peters and Timmerhaus, } \\
\text { 1991) }\end{array}$ \\
\hline & Pump $=0.80$ & $\begin{array}{l}\text { (Peters and Timmerhaus, } \\
1991)\end{array}$ \\
\hline & Electric motor $=0.90$ & (Peters and Timmerhaus, \\
\hline Oil loop pressure losses & $20 \mathrm{psi} \sim 1.4 \mathrm{~atm}$ & (Turton, et al., 2003) \\
\hline $\begin{array}{l}\text { Cooling water operating } \\
\text { temperatures }\end{array}$ & 303.15 to $313.15 \mathrm{~K}$ & (Turton, et al., 2003) \\
\hline Natural Gas lower heating value & $47 \mathrm{MJ} \cdot \mathrm{kg}^{-1}$ & $\begin{array}{l}\text { (Poulsen and Hansen, } \\
\text { 2003) }\end{array}$ \\
\hline
\end{tabular}


Table 2, "A new application of immersion frying for the thermal drying of sewage sludge: An economic assessment" by C. Peregrina, D. Lecomte, P. Arlabosse and V. Rudolph.

\begin{tabular}{|l|ccc|}
\hline Equipment & PROCESS 1 & PROCESS 2 & PROCESS 3 \\
\hline Fryer tank & 1 & 1 & 1 \\
Heat exchangers & 2 & 4 & 3 \\
Compressors & 0 & 2 & 2 \\
Pumps & 1 & 1 & 1 \\
Heater & 1 & 1 & 1 \\
TOTAL & 5 & 9 & 8 \\
\hline
\end{tabular}


Table 3, "A new application of immersion frying for the thermal drying of sewage sludge: An economic assessment” by C. Peregrina, D. Lecomte, P. Arlabosse and V. Rudolph.

\begin{tabular}{|c|c|c|c|}
\hline Equipment & \begin{tabular}{|l|} 
PROCESS 1 \\
\end{tabular} & \begin{tabular}{|l|} 
PROCESS 2 \\
\end{tabular} & \begin{tabular}{|l|} 
PROCESS 3 \\
\end{tabular} \\
\hline $\begin{array}{l}\text { V-101A,B,C,D } \\
\text { Fryer vessel }\end{array}$ & $\begin{array}{l}\mathrm{V}=6.0 \mathrm{~m}^{3} \\
\mathrm{P}=1 \mathrm{~atm} \\
\text { MOC }: \mathrm{SS} 304\end{array}$ & $\begin{array}{l}\mathrm{V}=: 5.7 \mathrm{~m}^{3} \\
\mathrm{P}=1 \mathrm{~atm} \\
\text { MOC }: \text { SS304 }\end{array}$ & $\begin{array}{l}\mathrm{V}=5.8 \mathrm{~m}^{3} \\
\mathrm{P}=1 \mathrm{~atm} \\
\text { MOC }: \mathrm{SS} 304\end{array}$ \\
\hline Axial tube fan & $\begin{array}{l}\text { Vol. flow }=0.36 \mathrm{~m}^{3 \cdot \mathrm{s}^{-1}} \\
\text { Electric motor }=1.4 \mathrm{kWW}\end{array}$ & $\begin{array}{l}\text { Vol. flow }=0.36 \mathrm{~m}^{3} \cdot \mathrm{s}^{-1} \\
\text { Electric motor }=1.4 \mathrm{~kW}\end{array}$ & $\begin{array}{l}\text { Vol. flow }=0.36 \mathrm{~m}^{3} \cdot \mathrm{s}^{-1} \\
\text { Electric motor }=1.4 \mathrm{~kW}\end{array}$ \\
\hline Belt conveyor & $\begin{array}{l}\text { Length }=169.3 \mathrm{~m} \\
\text { Width }=0.35 \mathrm{~m} \\
\text { Drive power }=10.8 \mathrm{~kW}\end{array}$ & $\begin{array}{l}\text { Length=159.6 m } \\
\text { Width }=0.35 \mathrm{~m} \\
\text { Drive power }=10.2 \mathrm{~kW}\end{array}$ & $\begin{array}{l}\text { Length }=162.8 \mathrm{~m} \\
\text { Width }=0.35 \mathrm{~m} \\
\text { Drive power }=10.3 \mathrm{~kW}\end{array}$ \\
\hline $\begin{array}{l}\text { E-101 } \\
\text { Heat exchanger }\end{array}$ & $\begin{array}{l}\text { Surface }=163.6 \mathrm{~m}^{2} \\
\text { Floating head } \\
\text { Tube side: } 1 \mathrm{~atm}, \text { SS } 304 \\
\text { Shell side : } 9 \mathrm{~atm}, \mathrm{CS} \\
\end{array}$ & $\begin{array}{l}\text { Floating head } \\
\text { Surface=82.9 } \mathrm{m}^{2} \\
\text { Tube side: } 1 \mathrm{~atm}, \text { SS } 304 \\
\text { Shell side : } 9 \text { atm, CS }\end{array}$ & $\begin{array}{l}\text { Floating head } \\
\text { Surface }=80.0 \mathrm{~m}^{2} \\
\text { Tube side: } 1 \mathrm{~atm}, \text { SS } 304 \\
\text { Shell side : } 9 \mathrm{~atm}, \mathrm{CS}\end{array}$ \\
\hline $\begin{array}{l}\text { E-201 } \\
\text { Heat exchanger }\end{array}$ & $\begin{array}{l}\text { Surface }=6.1 \mathrm{~m}^{2} \\
\text { Double pipe } \\
\mathrm{P}=1 \mathrm{~atm} \\
\mathrm{MOC}: \mathrm{CS}\end{array}$ & $\begin{array}{l}\text { Multiple pipe } \\
\text { Surface=50.6 } \mathrm{m}^{2} \\
\text { Tube side: } 1 \mathrm{~atm}, \mathrm{CS} \\
\text { Shell side : } 0.7 \mathrm{~atm}, \mathrm{CS} \\
\end{array}$ & $\begin{array}{l}\text { Multiple pipe } \\
\text { Surface=39.3 } \mathrm{m}^{2} \\
\text { Tube side: } 1 \mathrm{~atm}, \mathrm{SS} 304 \\
\text { Shell side }: 4 \mathrm{~atm}, \mathrm{CS}\end{array}$ \\
\hline $\begin{array}{l}\text { E-202 } \\
\text { Heat exchanger }\end{array}$ & $\mathrm{N} / \mathrm{A}$ & $\begin{array}{l}\text { Multiple pipe } \\
\text { Surface=33.2 } \mathrm{m}^{2} \\
\text { Tube side: } 1 \mathrm{~atm}, \mathrm{SS} 304 \\
\text { Shell side : } 4 \mathrm{~atm}, \mathrm{CS}\end{array}$ & $\begin{array}{l}\text { Double pipe } \\
\text { Surface }=1.9 \mathrm{~m}^{2} \\
\mathrm{P}=1 \mathrm{~atm} \\
\text { MOC }: \mathrm{CS}\end{array}$ \\
\hline $\begin{array}{l}\text { E-203 } \\
\text { Heat exchanger }\end{array}$ & $\mathrm{N} / \mathrm{A}$ & $\begin{array}{l}\text { Double pipe } \\
\text { Surface=2.6 } \mathrm{m}^{2} \\
\mathrm{P}=1 \mathrm{~atm} \\
\text { MOC }: \mathrm{CS}\end{array}$ & $\mathrm{N} / \mathrm{A}$ \\
\hline $\begin{array}{l}\text { C-201 } \\
\text { Compressor }\end{array}$ & $\mathrm{N} / \mathrm{A}$ & $\begin{array}{l}\text { Rotary } \\
\text { Elec. Power= }=65.4 \mathrm{~kW} \\
\text { P discharge }=1.9 \mathrm{~atm} \\
\text { T discharge }=525.82 \mathrm{~K} \\
\end{array}$ & $\begin{array}{l}\text { Rotary } \\
\text { Elec. Power }=50.9 \mathrm{~kW} \\
\text { P discharge }=2.2 \mathrm{~atm} \\
\text { T discharge }=499.03 \mathrm{~K}\end{array}$ \\
\hline $\begin{array}{l}\text { C-202 } \\
\text { Compressor }\end{array}$ & $\mathrm{N} / \mathrm{A}$ & $\begin{array}{l}\text { Rotary } \\
\text { Elec. Power }=66.6 \mathrm{~kW} \\
\text { P discharge }=4.0 \mathrm{~atm} \\
\text { T discharge }=682.09 \mathrm{~K} \\
\text { Efficiency }=0.65\end{array}$ & $\begin{array}{l}\text { Rotary } \\
\text { Elec. Power }=49.6 \mathrm{~kW} \\
P \text { discharge }=4.0 \mathrm{~atm} \\
\text { T discharge }=616.15 \mathrm{~K} \\
\text { Efficiency }=0.65\end{array}$ \\
\hline $\begin{array}{l}\text { H-101 } \\
\text { Steam generator }\end{array}$ & $\begin{array}{l}\text { Duty }=1033.2 \mathrm{~kW} \\
\mathrm{P}=9.0 \mathrm{~atm}\end{array}$ & $\begin{array}{l}\text { Duty }=420.8 \mathrm{~kW} \\
\mathrm{P}=9.0 \mathrm{~atm}\end{array}$ & $\begin{array}{l}\text { Duty }=455.5 \mathrm{~kW} \\
\mathrm{P}=9.0 \mathrm{~atm}\end{array}$ \\
\hline $\begin{array}{l}\text { P-101 } \\
\text { Pump }\end{array}$ & $\begin{array}{l}\text { Elec. Power }=5.5 \mathrm{~kW} \\
\text { Centrifugal } \\
\text { Efficiency }=0.8\end{array}$ & $\begin{array}{l}\text { Centrifugal } \\
\text { Elec. Power }=8.8 \mathrm{~kW} \\
\text { Efficiency }=0.8\end{array}$ & $\begin{array}{l}\text { Centrifugal } \\
\text { Elec. Power }=8.8 \mathrm{~kW} \\
\text { Efficiency }=0.8\end{array}$ \\
\hline
\end{tabular}


Table 4, "A new application of immersion frying for the thermal drying of sewage sludge: An economic assessment" by C. Peregrina, D. Lecomte, P. Arlabosse and V. Rudolph.

\begin{tabular}{|c|c|c|c|}
\hline Equipment & PROCESS 1 & PROCESS 2 & PROCESS 3 \\
\hline $\begin{array}{l}\text { V-101A,B,C,D } \\
\text { Fryer and accessories }\end{array}$ & \multirow{2}{*}{$\begin{array}{l}1.8 \times 10^{5} \\
1.9 \times 10^{5}\end{array}$} & $1.8 \times 10^{5}$ & $1.8 \times 10^{5}$ \\
\hline $\begin{array}{l}\text { E-101 } \\
\text { Heat exchanger }\end{array}$ & & $1.4 \times 10^{5}$ & $1.3 \times 10^{5}$ \\
\hline $\begin{array}{l}\text { E-201 } \\
\text { Heat exchanger }\end{array}$ & $1.3 \times 10^{4}$ & $1.1 \times 10^{5}$ & $6.8 \times 10^{4}$ \\
\hline $\begin{array}{l}\text { E-202 } \\
\text { Heat exchanger }\end{array}$ & $\mathrm{N} / \mathrm{A}$ & $6.6 \times 10^{4}$ & $1.4 \times 10^{4}$ \\
\hline $\begin{array}{l}\text { E-203 } \\
\text { Heat exchanger }\end{array}$ & $\mathrm{N} / \mathrm{A}$ & $1.9 \times 10^{4}$ & $\mathrm{~N} / \mathrm{A}$ \\
\hline $\begin{array}{l}\text { C-201 } \\
\text { Compressor }\end{array}$ & $\mathrm{N} / \mathrm{A}$ & $9.5 \times 10^{4}$ & $8.0 \times 10^{4}$ \\
\hline $\begin{array}{l}\text { C-202 } \\
\text { Compressor }\end{array}$ & $\mathrm{N} / \mathrm{A}$ & $8.4 \times 10^{4}$ & $7.8 \times 10^{4}$ \\
\hline $\begin{array}{l}\text { H-101 } \\
\text { Steam generator }\end{array}$ & $5.8 \times 10^{5}$ & $1.6 \times 10^{5}$ & $1.6 \times 10^{5}$ \\
\hline $\begin{array}{l}\text { P-101 } \\
\text { Pump }\end{array}$ & $1.6 \times 10^{4}$ & $1.6 \times 10^{4}$ & $1.6 \times 10^{4}$ \\
\hline $\begin{array}{l}\text { Total basic module cost } ; \mathrm{C}_{\mathrm{BM}_{0}} \\
\text { Total bare module cost } ; \mathrm{C}_{\mathrm{BM}} \\
\text { Contingency fees; } \mathrm{C}_{\mathrm{CF}}=0.18 \cdot \mathrm{C}_{\mathrm{BM}} \\
\text { Total module cost } \mathrm{C}_{\mathrm{TM}}=\mathrm{C}_{\mathrm{BM}}+\mathrm{C}_{\mathrm{CF}} \\
\text { Auxiliary facility cost } ; \mathrm{C}_{\mathrm{AC}}=0.3 \cdot \mathrm{C}_{\mathrm{BM}} \\
\text { Fixed capital cost } ; \mathrm{C}_{\mathrm{FC}}=\mathrm{C}_{\mathrm{TM}}+\mathrm{C}_{\mathrm{AC}} \\
\text { Working capital cost } ; \mathrm{C}_{\mathrm{WC}}=0.15 \cdot \mathrm{C}_{\mathrm{FC}}\end{array}$ & $\begin{array}{l}4.1 \times 10^{5} \\
9.8 \times 10^{5} \\
1.8 \times 10^{5} \\
1.2 \times 10^{6} \\
1.2 \times 10^{5} \\
1.3 \times 10^{6} \\
1.9 \times 10^{5}\end{array}$ & $\begin{array}{l}3.1 \times 10^{5} \\
8.7 \times 10^{5} \\
1.6 \times 10^{5} \\
1.0 \times 10^{6} \\
9.2 \times 10^{4} \\
1.1 \times 10^{6} \\
1.7 \times 10^{5}\end{array}$ & $\begin{array}{l}2.7 \times 10^{5} \\
7.3 \times 10^{5} \\
1.3 \times 10^{5} \\
8.6 \times 10^{5} \\
8.0 \times 10^{4} \\
9.4 \times 10^{5} \\
1.4 \times 10^{5}\end{array}$ \\
\hline Total capital investment; $\mathrm{C}_{\mathrm{TC}}=\mathrm{C}_{\mathrm{FC}}+\mathrm{C}_{\mathrm{WC}}$ & $1.5 \times 10^{6}$ & $1.3 \times 10^{6}$ & $1.1 \times 10^{6}$ \\
\hline
\end{tabular}


Table 5, "A new application of immersion frying for the thermal drying of sewage sludge: An economic assessment" by C. Peregrina, D. Lecomte, P. Arlabosse and V. Rudolph.

\begin{tabular}{|c|c|c|c|c|}
\hline Equipment & Description & PROCESS 1 & \begin{tabular}{|l} 
PROCESS 2 \\
\end{tabular} & PROCESS 3 \\
\hline $\begin{array}{l}\text { V-101A,B,C,D } \\
\text { Fan } \\
\text { Belt conveyor } \\
\text { Total }\end{array}$ & $\begin{array}{l}\text { Elec. Power (W) } \\
\text { Elec. Power (W) } \\
\text { Elec. Power (W) }\end{array}$ & \begin{tabular}{|l}
1372.8 \\
30.5 \\
1403.3
\end{tabular} & $\begin{array}{l}1372.8 \\
29.1 \\
1401.9\end{array}$ & $\begin{array}{l}1372.8 \\
29.3 \\
1402.1\end{array}$ \\
\hline $\begin{array}{l}\text { E-101 } \\
\text { Heat exchanger } \\
\text { H-101 }\end{array}$ & Steam $\left(\mathrm{kg} \cdot \mathrm{h}^{-1}\right)$ & 1918.4 & 824.4 & 861.1 \\
\hline Steam & Heat duty (W) & 1079417 & 488615 & 510211 \\
\hline & Fuel gas $\left(\mathrm{kg} \cdot \mathrm{h}^{-1}\right)$ & 82.7 & 37.4 & 39.1 \\
\hline $\begin{array}{l}\text { E-201 } \\
\text { Heat exchanger }\end{array}$ & Cooling water $\left(\mathrm{kg} \cdot \mathrm{h}^{-1}\right)$ & 38309.5 & 0 & 0 \\
\hline $\begin{array}{l}\text { C-201 } \\
\text { Compressor }\end{array}$ & Elec. Power (W) & 0 & 70593 & 61194 \\
\hline $\begin{array}{l}\text { C-202 } \\
\text { Compressor }\end{array}$ & Elec. Power (W) & 0 & 63615 & 59431 \\
\hline $\begin{array}{l}\text { P-101 } \\
\text { Pump }\end{array}$ & Elec. Power (W) & 7854.6 & 8755 & 8839.7 \\
\hline
\end{tabular}


Table 6, "A new application of immersion frying for the thermal drying of sewage sludge: An economic assessment" by C. Peregrina, D. Lecomte, P. Arlabosse and V. Rudolph.

\begin{tabular}{|c|c|c|c|}
\hline Cost & PROCESS 1 & PROCESS 2 & PROCESS 3 \\
\hline Direct manufacturing cost & & & \\
\hline Recycled cooking oil (293 USD $\cdot$ ton $^{-1}$ of RCO) ${ }^{*}$ & $4.5 \times 10^{5}$ & $4.5 \times 10^{5}$ & $4.5 \times 10^{5}$ \\
\hline Operating labor $; \mathrm{C}_{\mathrm{OL}}\left(23122 \mathrm{USD}_{\text {year }}\right)^{-1 *}$ & $1.4 \times 10^{5}$ & $1.6 \times 10^{5}$ & $1.6 \times 10^{5}$ \\
\hline Supervision and clerical labor ; $\mathrm{C}_{\mathrm{SC}}=0.15 \cdot \mathrm{C}_{\mathrm{OL}}$ & $2.1 \times 10^{4}$ & $2.4 \times 10^{4}$ & $2.4 \times 10^{4}$ \\
\hline Natural gas $\left(8.84 \mathrm{USD} \cdot \mathrm{GJ}^{-1}\right)^{* * *}$ & $1.2 \times 10^{5}$ & $5.0 \times 10^{4}$ & $5.4 \times 10^{4}$ \\
\hline Electricity $(0.07 \mathrm{USD} \cdot \mathrm{kWh})^{* * *}$ & $5.5 \times 10^{3}$ & $4.6 \times 10^{4}$ & $3.6 \times 10^{4}$ \\
\hline Cooling water $\left(0.02 \mathrm{USD} \cdot \mathrm{m}^{-3}\right)^{* * *}$ & $3.9 \times 10^{1}$ & 0 & 0 \\
\hline Maintenance and repairs ; $\mathrm{C}_{\mathrm{MR}}=0.6 \cdot \mathrm{C}_{\mathrm{FC}}$ & $7.4 \times 10^{4}$ & $6.3 \times 10^{4}$ & $5.3 \times 10^{4}$ \\
\hline Operating supplies $; \mathrm{C}_{\mathrm{OS}}=0.15 \cdot \mathrm{C}_{\mathrm{MR}}$ & $1.1 \times 10^{4}$ & $9.5 \times 10^{3}$ & $8.0 \times 10^{3}$ \\
\hline Laboratory charges $; \mathrm{C}_{\mathrm{LC}}=0.15 \cdot \mathrm{C}_{\mathrm{OL}}$ & $2.1 \times 10^{4}$ & $2.4 \times 10^{4}$ & $2.4 \times 10^{4}$ \\
\hline Patents and royalities ; $\mathrm{C}_{\mathrm{PR}}=0.03 \cdot \mathrm{C}_{\mathrm{TM}}$ & $4.3 \times 10^{4}$ & $4.2 \times 10^{4}$ & $4.0 \times 10^{4}$ \\
\hline Subtotal $\mathrm{A}_{\mathrm{DME}}$ & $8.9 \times 10^{5}$ & $8.7 \times 10^{5}$ & $8.5 \times 10^{5}$ \\
\hline \multicolumn{4}{|l|}{ Indirect manufacturing cost } \\
\hline $\begin{array}{l}\text { Overhead, packaging and storage } \\
\mathrm{C}_{\mathrm{MR}}=0.6 \cdot\left(\mathrm{C}_{\mathrm{OL}}+\mathrm{C}_{\mathrm{MR}}+\mathrm{C}_{\mathrm{SC}}\right)\end{array}$ & $1.4 \times 10^{5}$ & $1.5 \times 10^{5}$ & $1.4 \times 10^{5}$ \\
\hline Local taxes $; 0.015 \cdot \mathrm{C}_{\mathrm{FC}}$ & $1.9 \times 10^{4}$ & $1.6 \times 10^{4}$ & $1.3 \times 10^{4}$ \\
\hline Insurances $; 0.005 \cdot \mathrm{C}_{\mathrm{FC}}$ & $6.2 \times 10^{3}$ & $5.3 \times 10^{3}$ & $4.4 \times 10^{3}$ \\
\hline Depreciation ; $0.1 \cdot \mathrm{C}_{\mathrm{FC}}$ & $1.2 \times 10^{5}$ & $1.1 \times 10^{5}$ & $8.8 \times 10^{4}$ \\
\hline Subtotal & $2.9 \times 10^{5}$ & $2.8 \times 10^{5}$ & $2.5 \times 10^{5}$ \\
\hline \multicolumn{4}{|l|}{ General expenses } \\
\hline Aministrative costs $; \mathrm{C}_{\mathrm{ADMC}}=0.25 \cdot \mathrm{C}_{\mathrm{OPSL}}$ & $3.5 \times 10^{4}$ & $3.7 \times 10^{4}$ & $3.6 \times 10^{4}$ \\
\hline Distribution and selling; $\mathrm{C}_{\mathrm{ADMC}}=0.10 \cdot \mathrm{C}_{\mathrm{TM}}$ & $1.4 \times 10^{5}$ & $1.4 \times 10^{5}$ & $1.3 \times 10^{5}$ \\
\hline Research and development; $\mathrm{C}_{\mathrm{RD}}=0.25 \cdot \mathrm{C}_{\mathrm{OPSL}}$ & $7.1 \times 10^{4}$ & $7.0 \times 10^{4}$ & $6.7 \times 10^{4}$ \\
\hline Subtotal; $\mathbf{A}_{\mathrm{GE}}$ & $2.5 \times 10^{5}$ & $2.5 \times 10^{5}$ & $2.4 \times 10^{5}$ \\
\hline Total manufacturing cost $; \mathrm{C}_{\mathrm{TM}}$ & $1.4 \times 10^{6}$ & $1.4 \times 10^{6}$ & $1.3 \times 10^{6}$ \\
\hline
\end{tabular}

*Actualized from the RCO December 2004 price.(Sud-Recupération, 2003).

**Actualized from the 2002 industry worker salary (owvrier dans l'industrie) in France.(INSEE, 2005).

*** Actualized from Turton et al. 
Table 7, “A new application of immersion frying for the thermal drying of sewage sludge: An economic assessment" by C. Peregrina, D. Lecomte, P. Arlabosse and V. Rudolph.

\begin{tabular}{|c|c|c|c|c|c|c|}
\hline Drying facility & Location & $\begin{array}{c}\text { Capacity } \\
\left(\text { ton TS·year }{ }^{-1}\right)\end{array}$ & Published price & Updated price $†$ & $\begin{array}{c}\text { Ratio } \\
\text { (USD of investment/ton TS) }\end{array}$ & Reference \\
\hline $\begin{array}{l}\text { Thin film dryer }+ \\
\text { disc drver }\end{array}$ & Switzerland & 8000 & $4.5 \times 10^{6^{*}}$ & $4.6 \times 10^{6}$ & 572 & (Grüter, et al., 1990) \\
\hline Drum & Germany & 7799 & $15 \times 10^{6 * *}$ & $11.4 \times 10^{6}$ & 1459 & $\begin{array}{c}\text { (Hasserbrauck and } \\
\text { Ermel 1996) }\end{array}$ \\
\hline $\begin{array}{l}\text { Thin film dryer }+ \\
\text { disc drver }\end{array}$ & Germany & 6260 & $15 \times 10^{6 * *}$ & $11.4 \times 10^{6}$ & 1817 & $\begin{array}{c}\text { (Hasserbrauck and } \\
\text { Ermel 1996) }\end{array}$ \\
\hline Drum & France & 5093 & $14 \times 10^{6 * * *}$ & $3.1 \times 10^{6}$ & 608 & (Ressent, 1999) \\
\hline Belt & Germany & 2703 & $7.8 \times 10^{6 * * *}$ & $1.7 \times 10^{6}$ & 639 & (Ressent, 1999) \\
\hline Disc & France & 1539 & $9.0 \times 10^{6 * * *}$ & $2.0 \times 10^{6}$ & 1294 & (Ressent, 1999) \\
\hline
\end{tabular}

*Price in Swiss Francs $(1.2880 \mathrm{CHF}=1 \mathrm{USD})$

**Price in German Mark (1.6195DEM=1USD)

***Price in French Francs (5.4315FRF=1USD)

† Prices updated using the corresponding CEPCI Index and currency. $\mathrm{I}_{2005}=468.1 ; \mathrm{I}_{1998}=389.5 ; \mathrm{I}_{1995}=381.1$ and $\mathrm{I}_{1990}=357.6$. 


\section{Figures captions}

Figure 1 - Flow sheet of the simulated fry-drying operation

Figure 2 - PFD of a Fry-dryer with a condenser as an energy recovery system

Figure 3 - PFD of a Fry-dryer with a closed heat pump as an energy recovery system

Figure 4 - PFD of a Fry-dryer with an open heat pump as an energy recovery system

Figure 5 - Distribution of the direct manufacturing costs for the simulated fry-drying processes

Figure 6 - Distribution of the direct manufacturing costs for the conventional thermal dryers, according to Ressent (1998) 


\section{Figures}

Figure 1 "A new application of immersion frying for the thermal drying of sewage sludge: An economic assessment” by C. Peregrina, D. Lecomte, P. Arlabosse and V. Rudolph.

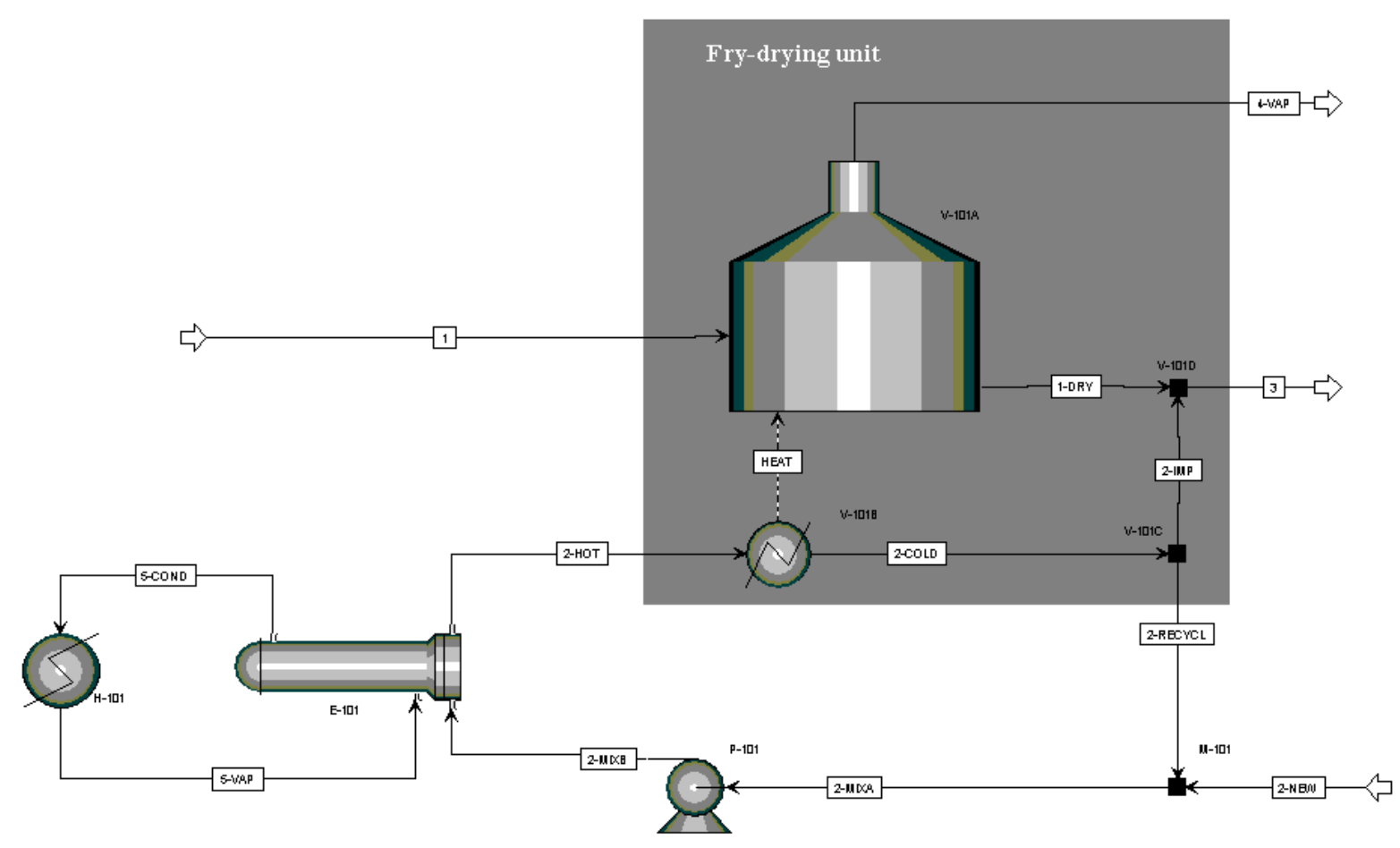


Figure 2, "A new application of immersion frying for the thermal drying of sewage sludge: An economic assessment" by C. Peregrina, D. Lecomte, P. Arlabosse and V. Rudolph.

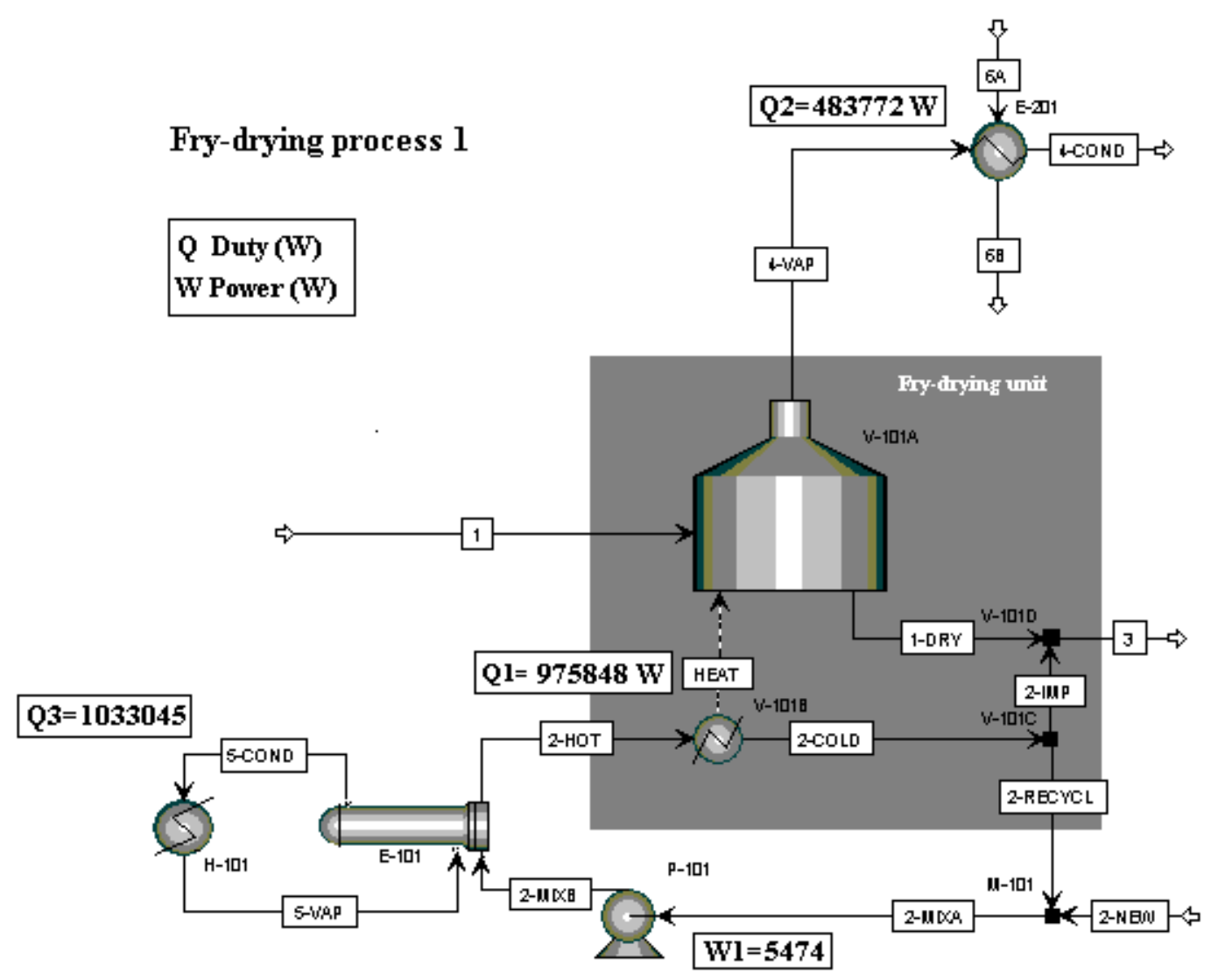

\begin{tabular}{|c|c|c|c|c|c|c|c|c|c|c|c|c|c|c|c|c|}
\hline Steam ID & 1 & 1-DRY & 2-COLD & 2-HОт & 2-IMP & 2-MIXA & 2-MIXB & 2-NEW & 2-RECYCL & 3 & 4-COND & 4-VAP & 5-COND & 5-VAP & $6 \mathrm{~A}$ & $6 \mathrm{~B}$ \\
\hline From & & $\mathrm{V}-101 \mathrm{~A}$ & V-101B & E-101 & $\mathrm{V}-101 \mathrm{C}$ & \begin{tabular}{|l|l}
$\mathrm{M}-101$ \\
\end{tabular} & \begin{tabular}{|l|l|} 
P-101 \\
\end{tabular} & & $\mathrm{V}-101 \mathrm{C}$ & \begin{tabular}{|l|}
$\mathrm{V}-101 \mathrm{D}$ \\
\end{tabular} & E-201 & $\mathrm{V}-101 \mathrm{~A}$ & \begin{tabular}{|l|} 
E-101 \\
\end{tabular} & $\mathrm{H}-101$ & & E-201 \\
\hline $\begin{array}{l}\text { Tom } \\
\text { To } \\
\end{array}$ & $\mathrm{V}-101 \mathrm{~A}$ & 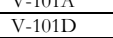 & \begin{tabular}{|l|l|l|l|l|l|l|} 
V-101C \\
\end{tabular} & $\begin{array}{l}\frac{1}{2}-1011 \mathrm{~B} \\
\mathrm{~V}-101 \mathrm{~B}\end{array}$ & \begin{tabular}{|l|l}
-1-101C \\
V-101D
\end{tabular} & \begin{tabular}{|l|l}
$\mathrm{M}-101$ \\
$\mathrm{P}-101$ \\
\end{tabular} & \begin{tabular}{|l|l|l|l|l|l|l|}
$E-101$ \\
\end{tabular} & \begin{tabular}{|l|} 
M-101 \\
\end{tabular} & \begin{tabular}{|l|l|l|l|l|l|l|} 
M-101 \\
\end{tabular} & & & 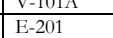 & \begin{tabular}{|l|l|} 
E-101 \\
-101 \\
\end{tabular} & $\frac{H-1101}{E-101}$ & E-201 & \\
\hline $\begin{array}{l}10 \\
\text { Temperature }(\mathrm{K})\end{array}$ & \begin{tabular}{|l|l}
$\mathrm{V}-101 \mathrm{~A}$ \\
283.15 \\
\end{tabular} & \begin{tabular}{|c|c|c|}
-1011 \\
375.62
\end{tabular} & 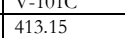 & $\frac{-101 \mathrm{D}}{433.15}$ & \begin{tabular}{|l|l|l|l|l|l|}
413.15 \\
\end{tabular} & \begin{tabular}{|l|l|l|l|l|l|}
$p 11.96$ \\
\end{tabular} & \begin{tabular}{|l|l|} 
E-101 \\
411.96 \\
\end{tabular} & \begin{tabular}{|l|l|} 
M-101 \\
283.15 \\
\end{tabular} & \begin{tabular}{|l|l|l|l|l|l}
413.15 \\
\end{tabular} & 375.62 & 368.15 & \begin{tabular}{|l|l|} 
E-201 \\
375.62 \\
\end{tabular} & \begin{tabular}{|l|l|}
$4-101$ \\
449.61 \\
\end{tabular} & $\begin{array}{ll}\text { C-101 } \\
449.61\end{array}$ & 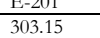 & 313.15 \\
\hline $\begin{array}{l}\text { Iemperature }(\mathrm{K}) \\
\text { Pressure }(\mathrm{atm})\end{array}$ & $\frac{\mid 83.15}{1.000}$ & 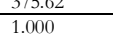 & \begin{tabular}{|l|l|l|l|l|l|l|}
1.000 \\
\end{tabular} & 1.000 & \begin{tabular}{|l|l|l|l|l|l}
1.000 \\
\end{tabular} & $\begin{array}{l}11.90 \\
1.000 \\
\end{array}$ & \begin{tabular}{|l|l|}
41.900 \\
1.000
\end{tabular} & \begin{tabular}{|l|l|l|l|l|l|l|}
1.000 \\
\end{tabular} & \begin{tabular}{|l|l|l|l|l|l|}
1.000 \\
\end{tabular} & \begin{tabular}{|l|l|l|l|l|l|}
1.000 \\
\end{tabular} & 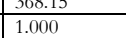 & 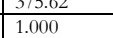 & \begin{tabular}{|l|l|}
94.000 \\
9
\end{tabular} & $\begin{array}{l}44.000 \\
9.000\end{array}$ & $\frac{303.13}{1.000}$ & \begin{tabular}{|l|l|l|l|l|l|l|}
1.000 \\
\end{tabular} \\
\hline $\begin{array}{l}\text { Tressure (atmi) } \\
\text { Mass flow }\left(\mathrm{kghr}^{-1}\right)\end{array}$ & $\begin{array}{l}1.000 \\
5263.000\end{array}$ & \begin{tabular}{|l|l|}
1.000 \\
4500.006
\end{tabular} & \begin{tabular}{|l|l|}
1.000 \\
78465.42
\end{tabular} & $\frac{1.000}{78465.42}$ & $\frac{1.000}{350.000}$ & \begin{tabular}{|l|l|}
784605.42 \\
\end{tabular} & \begin{tabular}{|l|}
1.000 \\
78465.42 \\
\end{tabular} & \begin{tabular}{|l|l|}
1.000 \\
350.000
\end{tabular} & \begin{tabular}{|l|l|}
7800 \\
78115.42 \\
\end{tabular} & \begin{tabular}{|l|}
1.000 \\
4850.000 \\
\end{tabular} & $\frac{1.000}{763.000}$ & $\frac{1.1000}{763.000}$ & \begin{tabular}{|l|}
18000 \\
1834.917
\end{tabular} & $\frac{1.000}{1834.917}$ & $\frac{1.000}{41739.110}$ & \begin{tabular}{|l|l|}
1.000 \\
41739.110 \\
\end{tabular} \\
\hline \multirow{2}{*}{\multicolumn{17}{|c|}{ 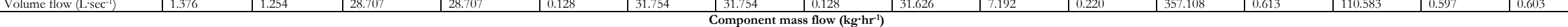 }} \\
\hline & & & & & & & & & & & & & & & & \\
\hline Total dry solids & 1000.000 & 1000.000 & 0 & 0 & 0 & 0 & 0 & 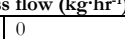 & 0 & 1000.000 & 0 & 0 & 0 & 0 & & \\
\hline Water & 4263.000 & 3500.006 & \begin{tabular}{|l|l|}
0 \\
\end{tabular} & 0 & \begin{tabular}{|l|l}
0 \\
\end{tabular} & 0 & \begin{tabular}{|l|l|}
0 \\
\end{tabular} & \begin{tabular}{|l|l|}
0 \\
\end{tabular} & \begin{tabular}{|l|l|}
0 \\
\end{tabular} & \begin{tabular}{|l|l}
3500.006 \\
\end{tabular} & \begin{tabular}{|l}
763.000 \\
\end{tabular} & \begin{tabular}{|l}
763.000 \\
\end{tabular} & \begin{tabular}{|l|l|}
1834.917 \\
\end{tabular} & 1834.917 & 41739.110 & 41739.110 \\
\hline RCO & & & \begin{tabular}{|l}
78465.42 \\
\end{tabular} & 78465.42 & 350.000 & 788465.42 & \begin{tabular}{|l}
78465.42 \\
\end{tabular} & \begin{tabular}{|l|}
350.000 \\
\end{tabular} & \begin{tabular}{|l|l}
86443.53 \\
\end{tabular} & \begin{tabular}{|l|l|}
350.000 \\
\end{tabular} & & & & & & \\
\hline
\end{tabular}


Figure 3 "A new application of immersion frying for the thermal drying of sewage sludge: An economic assessment” by C. Peregrina, D. Lecomte, P. Arlabosse and V. Rudolph.

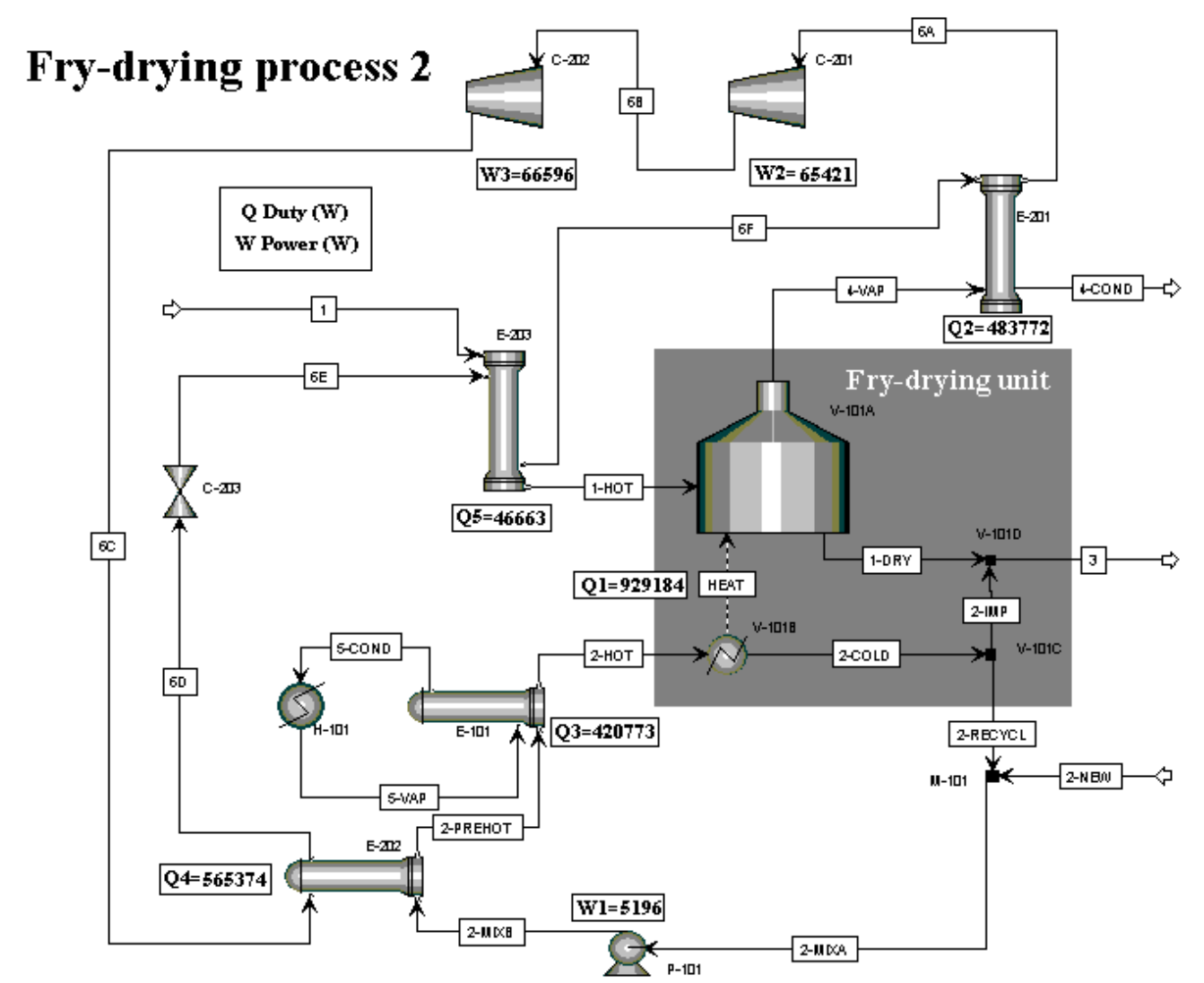

\begin{tabular}{|c|c|c|c|c|c|c|c|c|c|c|c|c|c|c|c|c|c|c|c|c|c|c|}
\hline Steam ID & 1 & 1-DRY & 1-НОт & 2-COLD & 2-НОт & 2-IMP & 2-MIXA & 2-MIXB & 2-NEW & 2-PREHOT & 2-RECYCL & 3 & 4-COND & 4-VAP & 5-COND & 5-VAP & $6 \mathrm{~A}$ & $6 \mathrm{~B}$ & $6 \mathrm{C}$ & $6 \mathrm{D}$ & $6 \mathrm{E}$ & $6 \mathrm{~F}$ \\
\hline From & & $\mathrm{V}-101 \mathrm{~A}$ & -203 & $101 \mathrm{~B}$ & E-101 & $-101 \mathrm{C}$ & 01 & 01 & & 02 & \begin{tabular}{l|l}
$\mathrm{V}-101 \mathrm{C}$ \\
\end{tabular} & V-101D & E-201 & $\mathrm{A}$ & E-101 & 11 & $\begin{array}{lll}11 & \end{array}$ & C-201 & 02 & $\overline{E-202}$ & 03 & E- -2 \\
\hline - & E-203 & $\mathrm{V}-1$ & & V-101C & & \begin{tabular}{ll|}
$\mathrm{V}-101 \mathrm{D}$ \\
\end{tabular} & & & M-101 & & M-101 & & & E- & & & & & & & & \\
\hline peratur & & & & & 433.15 & & & & & & & 375.6 & 368.15 & & & & & & & & & 362.00 \\
\hline$\frac{\text { Iemmetratu }}{\text { Pressure }(\mathrm{a}}$ & $\frac{283.15}{1.000}$ & & & & & & & & & & & $\frac{0.36}{1.06}$ & & & & & & & & & 300.24 & S02.00 \\
\hline$\frac{\text { Mressure at }}{\text { Mass flow } 1}$ & $\frac{1.0000}{263.000}$ & $\begin{aligned} 1.0000 \\
4500.000\end{aligned}$ & $\begin{array}{r}1.000 \\
5263.000 \\
\end{array}$ & $\frac{1.000}{74713.34}$ & $\frac{1.000}{74713.34}$ & \begin{tabular}{rl|l}
350.000 \\
\end{tabular} & \begin{tabular}{r|}
1.000 \\
74713.34 \\
\end{tabular} & $\frac{1.000}{74713.34}$ & & $\frac{1.000}{74713.34}$ & $\frac{1.000}{74363.34}$ & $\frac{1.000}{4850.000}$ & $\frac{1.000}{763.000}$ & 763.000 & $\frac{1.000 \mid}{747.387}$ & 747.387 & & 759.320 & $\begin{array}{ll}4.000 \\
759.320 \\
\end{array}$ & \begin{tabular}{l|l}
459.320 \\
759.320
\end{tabular} & \begin{tabular}{l|l}
759.320 \\
\end{tabular} & $\frac{0.7}{759.320}$ \\
\hline$\frac{\text { Mass flow }\left(\mathrm{kg} \cdot \mathrm{ghr}^{-1}\right)}{\text { Volume flow }\left(\mathrm{L} \cdot \mathrm{sec}^{-1}\right)}$ & $\frac{60.000}{1.366}$ & 年00.000 & $\begin{array}{r}52030.000 \\
1.377\end{array}$ & $\frac{74.15344}{27.334}$ & $\frac{141.3 .34}{27.334}$ & $\begin{array}{l}530.000 \\
0.128 \\
\end{array}$ & $\begin{array}{r}741.3 .34 \\
27.334 \\
\end{array}$ & $\frac{741.1534}{27.334}$ & $\frac{300.000}{0.128}$ & 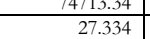 & 年63.3.54 & $\frac{4850.000}{7.192}$ & $\frac{1030000}{0.220}$ & $\begin{array}{ll}70.5000 \\
357.109 \\
\end{array}$ & $\frac{\mid \frac{174.381}{0.233}}{1}$ & $\begin{array}{l}74.8 .07 \\
4.069 \\
\end{array}$ & \begin{tabular}{l|}
159.520 \\
496.657
\end{tabular} & $\frac{159,20}{264.138}$ & $\frac{\mid \frac{75.920}{162.971}}{4}$ & 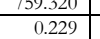 & 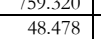 & $\frac{59.320}{0.218}$ \\
\hline & & & & & & & & & & pponent ma & $\left(\mathrm{kg} \cdot \mathrm{hr} \mathrm{r}^{-1}\right)$ & & & & & & & & & & & \\
\hline $\begin{array}{l}\text { Total dry } \\
\end{array}$ & 0.000 & \begin{tabular}{ll|}
1000.000 \\
\end{tabular} & 40 & 0 & 0 & 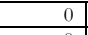 & 4 & 0 & 0 & 0 & 0 & 1000.000 & & & 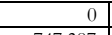 & & & & & & 0 & \\
\hline Water & 4263.000 & 3500.000 & 4263.000 & $\begin{array}{r}0 \\
71712.29\end{array}$ & & 0 & & 0 & 0 & $\begin{array}{l}0 \\
\end{array}$ & 0 & 3500.000 & 763.000 & 763.000 & 747.387 & 747.387 & 759.320 & 759.320 & 759.320 & 759.320 & 759.320 & 9.320 \\
\hline $\mathrm{RCO}$ & & & & 74713.34 & 84713.34 & 350.000 & 74713.34 & 74713.34 & 350.000 & 74713.34 & 74363.34 & 350.000 & & & & & & & & & & \\
\hline
\end{tabular}


Figure 4 "A new application of immersion frying for the thermal drying of sewage sludge: An economic assessment" by C. Peregrina, D. Lecomte, P. Arlabosse and V. Rudolph.

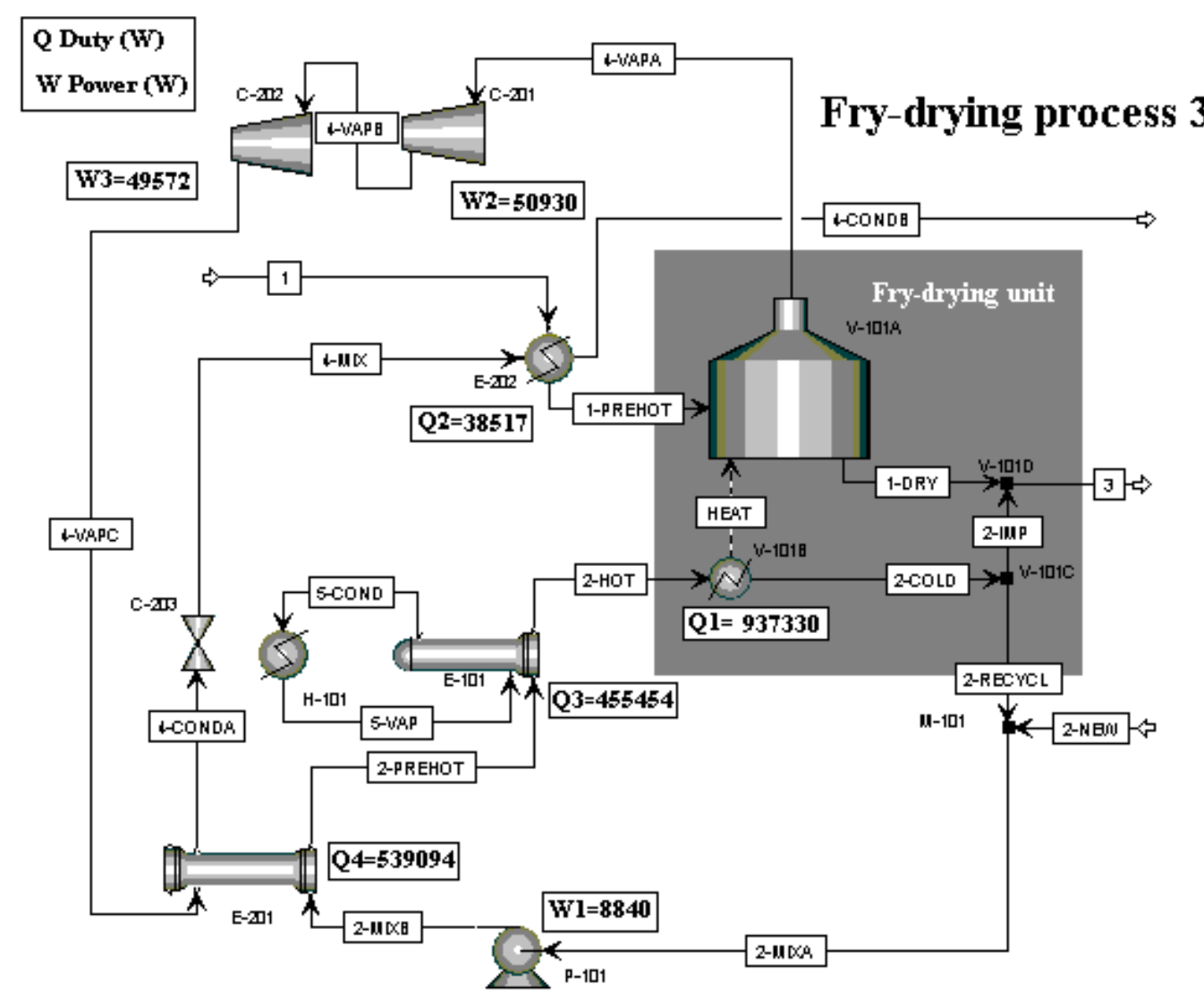

\begin{tabular}{|c|c|c|c|c|c|c|c|c|c|c|c|c|c|c|c|c|c|c|c|c|}
\hline Steam ID & 1 & 1-DRY & 1-НОт & 2-COLD & 2-нот & 2-IMP & 2-MIXA & 2-MIXB & 2-NEW & 2-РREHOT & 2-RECYCL & 3 & 4-CONDA & 4-CONDB & 4-MIX & 4-VAPA & 4-VAPB & 4-VAPC & 5-COND & 5-VAP \\
\hline From & & $101 \mathrm{~A}$ & E-20 & V-101B & E-101 & $\mathrm{V}-101$ & M-101 & P-101 & & E-201 & $\mathrm{V}-10$ & $\mathrm{~V}-101 \mathrm{D}$ & E-201 & E-202 & $\mathrm{C}-2$ & $\mathrm{~V}-101 \mathrm{~A}$ & 201 & $\mathrm{C}-202$ & E-101 & H-101 \\
\hline To & E-202 & & & $\mathrm{V}-$ & & & & & M-101 & & $M_{1}$ & & & & & & & & & 101 \\
\hline Tempera & 283.15 & 37 & 290.33 & 41 & 43 & & & & & $\frac{42}{42}$ & & 37 & & 37. & & & & & & 49.62 \\
\hline & 1.000 & & & & & & & & & & & & & & & & & & & \\
\hline & 63.000 & 4500.0 & 5263.000 & 75368.36 & 75368.36 & 350.000 & 75368.36 & 75368.36 & 350. & 75368.36 & 55018.36 & 4850.000 & 763.000 & $\frac{1 .}{763 .}$ & $\frac{1.4}{763 .}$ & $\frac{1}{663}$ & $\frac{2}{763}$ & $\frac{7.000}{763.000}$ & 805.091 & 805.091 \\
\hline Volume flow $\left(\mathrm{L} \cdot \mathrm{sec}^{-1}\right)$ & 1.366 & 1.208 & 1.377 & 27.574 & 27.574 & 0.128 & 27.574 & 27.574 & 0.128 & 27.574 & 27.446 & 7.912 & 0.230 & 0.220 & 29.033 & 57.108 & 216.929 & 147.580 & 0.251 & $\frac{830.025}{48.025}$ \\
\hline \multicolumn{21}{|l|}{ Volume flow (L'sec-1) } \\
\hline Total dry & 1000.000 & 1000. & 1000.000 & 0 & 0 & 0 & 0 & 0 & $F$ & 0 & 0 & & & & & & & & & \\
\hline Water & 4263.000 & 3500.000 & 4263.000 & 0 & 0 & 0 & 0 & 0 & 0 & 0 & 0 & 3500.000 & 763.000 & 763.000 & 763.000 & 763.000 & 763.000 & 763.000 & 05.091 & 091 \\
\hline $\mathrm{RCO}$ & & & & 75368.36 & 75368.36 & 350.000 & 75368.36 & 75368.36 & 350.000 & 85368.36 & 75018.36 & 350.000 & & & & & & & & \\
\hline
\end{tabular}


Figure 5, "A new application of immersion frying for the thermal drying of sewage sludge: An economic assessment” by C. Peregrina, D. Lecomte, P. Arlabosse and V. Rudolph.

Fry-drying PROCESS 1

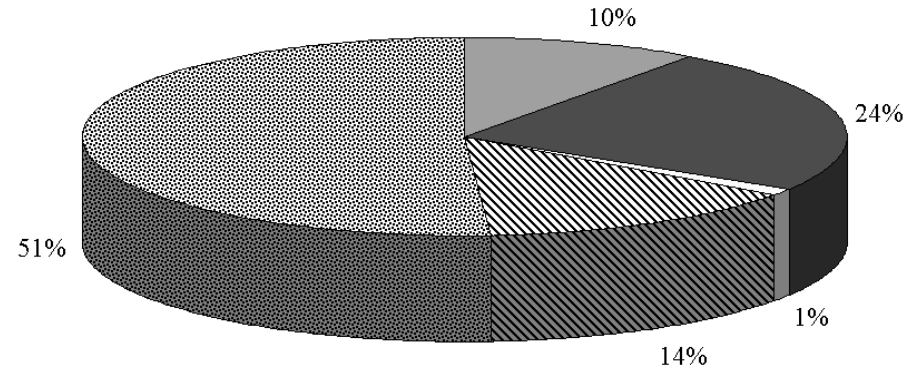

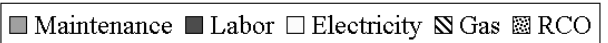

Fry-drying PROCESS 2

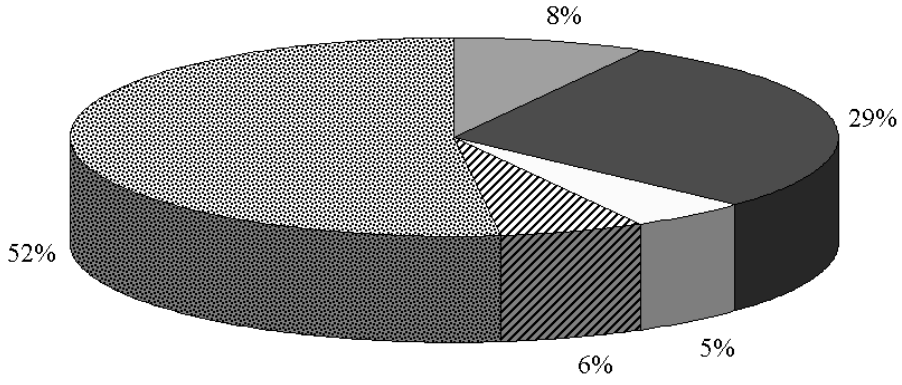

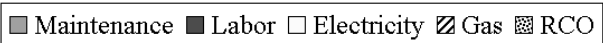

(b)

Fry-drying PROCESS 3

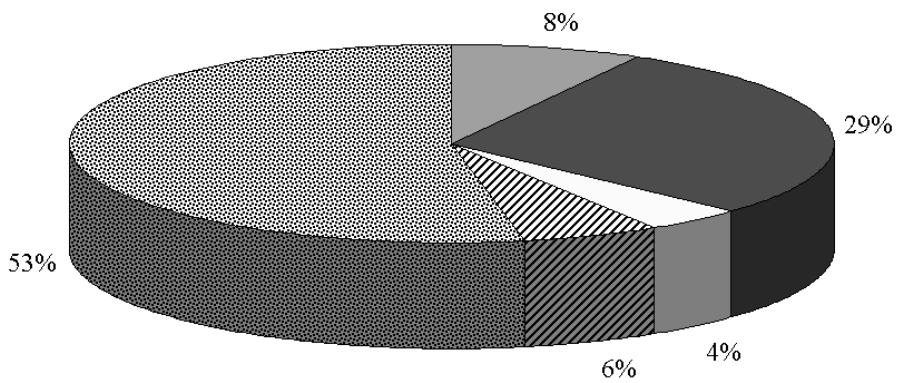

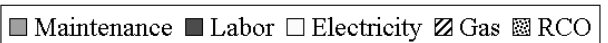

(c) 
Figure 6, "A new application of immersion frying for the thermal drying of sewage sludge: An economic assessment” by C. Peregrina, D. Lecomte, P. Arlabosse and V. Rudolph.

\section{Indirect drying}

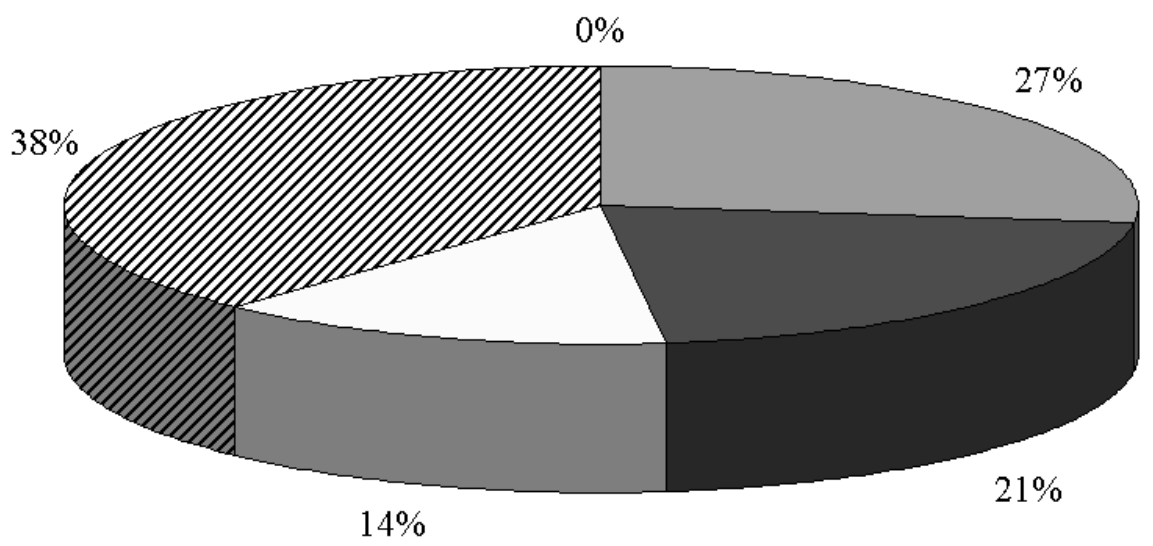

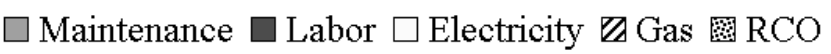

Direct drying

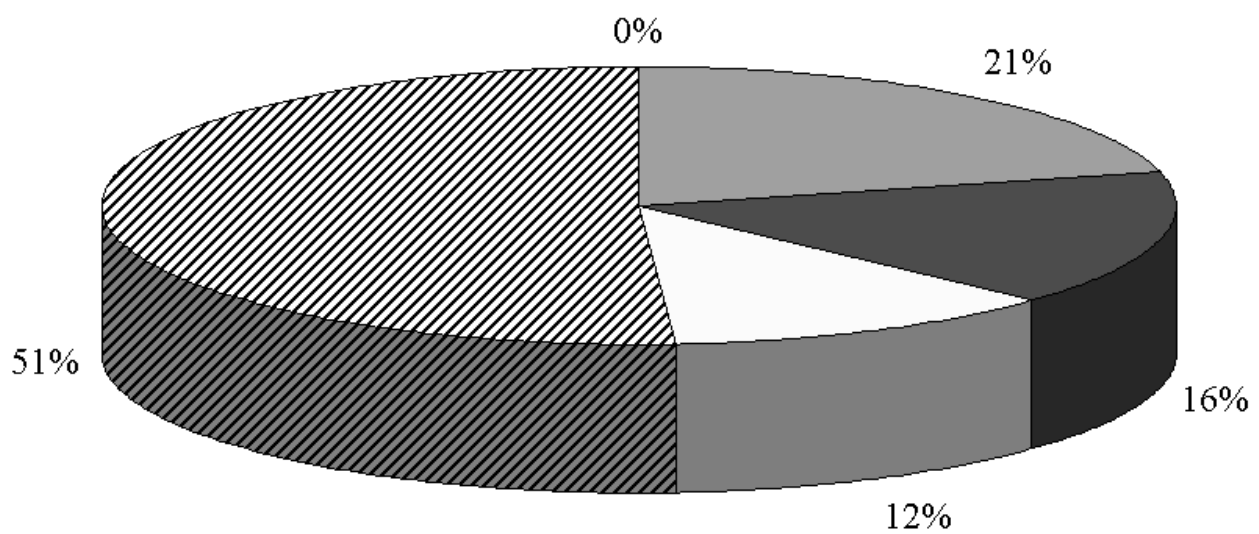

$\square$ Maintenance $\square$ Labor $\square$ Electricity $\mathbb{Z}$ Gas 圈 RCO 


\section{REFERENCES}

ADEME, 1998, http://www.ademe.fr/partenaires/boues/default.htm, August 2005.

Alkayat, W.A. and Gerrard, A.M., 1984. Estimating manning levels for process plants. AACE transactions. I.2.1-I.2.4.

Arlabosse, P., 2001, Etude des procédés de séchage des boues urbaines et industrielles, Ecole des Mines d'Albi Carmaux \& Association RE.CO.R.D., Albi, France, pp. 184.

Boatella-Riera, J., Codony, R., Rafecas, M. and Guardioal, F., 2000, Recycled cooking oils: Assessments of risk for public health, European Parliament, Luxembourg, pp. 100.

Bress, D.F., Greenfield, B.S. and Haug, R.T., 1987. Energy from sludge derived fuels: The Hyperion Energy Recovery System, in: Klass, D. and Donald, L. (Eds), Energy from biomass waste X. Institute of Gas technology, Chicago, Illinois, USA, pp. 1173-1182.

Cano-Ruiz, J.A. and McRae, G.J., 1998. Environmentally conscious chemical process design. Annual Review of Energy and the Environment. 23, 499-536.

Chen, G., Yue, P.L. and Mujumdar, A.S., 2002. Sludge Dewatering and Drying. Drying Technology. 20, 883-916.

Christiannsen, K.M., 1999, Waste Annual topic update 1998, European Environment Agency, Copenhagen, Danemark, pp. 43.

Couturier, C., Berger, S., Hérault, I. and Meiffren, I., 2001, La digestion anaérobie des boues urbaines: état des lieux, état de l'art, Agence de l'eau Adour-Garonne \& Solagro, Toulouse, France, pp. 36.

Farkas, B.E. and Hubbard, L.J., 2000. Analysis of convective heat transfer during immersion frying. Drying Technology. 18, 1269-1285.

Garayo, J. and Moreira, R., 2002. Vacuum frying of potato chips. Journal of Food Engineering. 55, 181-191.

Graille, J., 1998. Réactions chimiques induites par la friture. OCL, Oléagineux Corps Gras Lipides. 5, 36-40.

Gross, T.S.C., 1993. Thermal drying of sewage sludge. Journal of the Institution of Water and Environmental Management. 7, 255-261.

Grueter, H., Matter, M., Oehlmann, K.H. and Hicks, M.D., 1990. Drying of sewage sludge. An important step in waste disposal. Water Science and Technology. 22, 57-63.

Grüter, H., Matter, M., Oehlmann, K.H. and Hicks, M.D., 1990. Drying of sewage sludge. An important step in waste disposal. Water Science and Technology. 22, 57-63.

Hasserbrauck, M. and Ermel, G., 1996. Two examples of thermal drying of sewage sludge. Water Science and Technology. 33, 235-242.

IEA, 2004, http://www.heatpumpcentre.org/, 1 December 2004.

INSEE, 2005, http://www.insee.fr/fr/ffc/chifcle fiche.asp?ref id=NATSEF04122\&tab id=508, September 2005.

Kudra, T., 2004. Energy aspects in drying. Drying Technology. 22, 917-932.

Kuntschar, W., 1996, Verfahren und Vorrichtung zum Trocknen von Klärschlamm: Process and equipment for the sludge drying, Germany, Patent: DE19639551C1, (30 April 1998)

Lowe, P., 1995. Developments in the thermal drying of sewage sludge. Journal of the chartered institution of water and environmental management. 9, 306.

Lue-Hing, C., Matthews, P., Namer, J., Okuno, N. and Spinosa, L., 1996. Sludge management in highly urbanized areas. Water Science and Technology. 34, 517-524.

McGill, E.A., 1980. The Chemistry of frying. Backer's digest. 54, 38-42.

Möller, U., 1990. Klärschlammbehandlung - verwertung und Entsorgunug auf weiter gesteigertm Niveau unte Einsatz von Klärschlammtrocknung. Abwassertechnik, Abfalltechnik \& Recycling. 16 - 22. 
Moreira, R., Castell-Perez, M. and Barrufet, M., 1999. Deep-fat frying: Fundamentals and applications, ed. Aspen publication, Gaithersutg, Maryland, U.S.A.

Munck-Kampmann, B., 2001, Waste Annual topic update 2000, European Environment Agency, Copenhagen, Danemark, pp. 24.

Peregrina, C., Lecomte, D., Arlabosse, P. and Rudolph, V., 2005a. Analysis of heat and mass transfer during fry-drying of sewage sludge. Drying Technology. Submitted for publication,

Peregrina, C., Lecomte, D., Arlabosse, P. and Rudolph, V., 2005b. Life cycle assessment (LCA) applied to the design of an innovative drying process for sewage sludge. Process Safety and Environmental Protection. Submitted for publication,

Peregrina, C., Lecomte, D., Arlabosse, P. and Rudolph, V., In press-a. Analysis of heat and mass transfer during fry-drying of sewage sludge. Drying Technology.

Peregrina, C., Lecomte, D., Arlabosse, P. and Rudolph, V., In press-b. Life cycle assessment (LCA) applied to the design of an innovative drying process for sewage sludge. Process Safety and Environmental Protection.

Peters, M.S. and Timmerhaus, K.D., 1991. Plant design and economics for chemical engineers, 4th ed. McGraw-Hill, New York, USA.

Poulsen, T.G. and Hansen, J.A., 2003. Strategic environmental assessment of alternative sewage sludge management scenarios. Waste Management and Research. 21, 19-28.

Powell, R.L., 2002. CFC phase-out: have we met the challenge? Journal of Fluorine Chemistry. 114, 237-250.

Ressent, S., 1998, Etat de l'art sur le séchage thermique de boues urbaines et industrielles, Agence de l'eau Seine-Normandie, Paris, France, pp. 358.

Ressent, S., 1999, Campagnes de mesure realisés sur des séchoirs de boues urbaines et industrielles, Agence de l'eau Seine-Normandie, Paris, France, pp. 268.

Riffat, S.B., Afonso, C.F., Oliveira, A.C. and Reay, D.A., 1997. Natural refrigerants for refrigeration and air-conditioning systems. Applied Thermal Engineering. 17, 33-42.

Saguy, S., Ufheil, G. and Livings, S., 1998. Oil uptake in deep-fat frying: review. OCL, Oléagineux Corps Gras Lipides. 5, 30-35.

Sinnott, J.F., 1991. An Introduction to Chemical Engineering Design, ed. Pergamon Press, Oxford, UK.

Stier, R.F., 1996a. Understanding High-Volume Frying. Part 1. Backing \& Snack. 70-76.

Stier, R.F., 1996b. Understanding High-Volume Frying. Part 2. Baking \& Snack. 51-54.

Stier, R.F., 1996c. Understanding High-Volume Frying. Part 3. Backing \& Snack. 41-44.

Sud-Recupération, 2003, www.sud-recuperation.fr/traitement.html, August 2005.

Tong, L.S. and Tang, Y.S., 1997. Boiling heat transfer and two-phase flow, 2nd ed. Taylor and Francis, London, U.K.

Treybal, R.E., 1980. Drying, in: (Eds), Mass-transfer operations. McGraw-Hill, New York, USA, pp. 858.

Tsai, W.-T., An overview of environmental hazards and exposure risk of hydrofluorocarbons (HFCs). Chemosphere. In Press, Corrected Proof,

Turton, R., Bailie, R.C., Whiting, W.B. and Shaeiwitz, J.A., 1998. Analysis, Synthesis, and Design of Chemical Processes, ed. Prentice Hall PTR, New York.

Turton, R., Bailie, R.C., Whiting, W.B. and Shaeiwitz, J.A., 2003. Analysis, Synthesis, and Design of Chemical Processes, 2nd ed. Prentice Hall PTR, New York, USA.

Twu, C.H., Coon, J.E. and Bluck, D., 1998. Comparison of the Peng-Robinson and SoaveRedlich-Kwong equations of state using a new zero-pressure-based mixing rule for the prediction of high-pressure and high-temperature phase equilibria. Industrial \& Engineering Chemistry Research. 37, 1580-1585.

Twu, C.H., Sim, W.D. and Tassone, V., 2002. Getting a handle on advanced cubic equations of state. Chemical Engineering Progress. 98, 58-65. 
Urich, G.D., 1984. A guide to chemical engineering process design and economics, ed. John Wiley \& Sons, New York, USA.

Vatavuk, W.M., 2002. Updating the CE Plant Cost Index. Chemical Engineering Magazine. 6270.

Vaxelaire, J., Bongiovanni, J.M., Mousques, P. and Puiggali, J.R., 2000. Thermal drying of residual sludge. Water Research. 34, 4318-4323.

Vesilind, P.A. and Hsu, C.C., 1997. Limits of sewage dewaterability. Water Science and Technology. 36, 87-91.

Werther, J. and Ogada, T., 1999. Sewage sludge combustion. Progress in Energy and Combustion Science. 25, 55-116.

Zhang, Y., Dube, M.A., McLean, D.D. and Kates, M., 2003a. Biodiesel production from waste cooking oil: 1. Process design and technological assessment. Bioresource Technology. 89, $1-16$.

Zhang, Y., Dube, M.A., McLean, D.D. and Kates, M., 2003b. Biodiesel production from waste cooking oil: 2. Economic assessment and sensitivity analysis. Bioresource Technology. 90, $229-240$ 